\title{
Quaternary ammonium compounds in soil: implications for antibiotic resistance development
}

\author{
Ines Mulder $\mathbb{D} \cdot$ Jan Siemens • Valerie Sentek - Wulf Amelung • \\ Kornelia Smalla $\cdot$ Sven Jechalke
}

Published online: 5 December 2017

(C) The Author(s) 2017. This article is an open access publication

\begin{abstract}
Quaternary ammonium compounds (QACs) are surface-active, antimicrobial, high production volume (HPV) chemicals with a broad application in agriculture. This review provides a comprehensive overview of (1) predicted and measured concentrations of QACs in soils including their analysis, (2) sequestration mechanisms in soils based on their physicochemical properties and chemical structure, and (3) implications of concentrations and fate of QACs in soils for the proliferation of antibiotic resistance in the environment. Predicted environmental concentrations (PEC) for QACs that are applied to
\end{abstract}

Electronic supplementary material The online version of this article (https://doi.org/10.1007/s11157-017-9457-7) contains supplementary material, which is available to authorized users.

\footnotetext{
I. Mulder $(\bowtie) \cdot$ J. Siemens

Institute of Soil Science and Soil Conservation, iFZ

Research Center for BioSystems, Land Use and Nutrition,

Justus Liebig University Giessen, Heinrich-Buff-Ring

26-32, 35392 Giessen, Germany

e-mail: ines.mulder@umwelt.uni-giessen.de

V. Sentek · W. Amelung

Institute of Crop Science and Resource Conservation -

Soil Science and Soil Ecology, University of Bonn,

Nussallee 13, 53115 Bonn, Germany

K. Smalla

Institute for Epidemiology and Pathogen Diagnostics,

Julius Kühn-Institut - Federal Research Centre for

Cultivated Plants (JKI), Messeweg 11-12,

38104 Brunswick, Germany
}

soils with manure are in the order of $3.5 \mathrm{mg} \mathrm{kg}^{-1}$. Based on literature data, the median PEC of QAC in sewage sludge amended soils is $25 \mu \mathrm{g} \mathrm{kg}^{-1}$. The positively charged QACs are mainly sorbed to clay minerals. We propose that QACs might be sequestered in the interlayer regions of layered silicates in clayrich soils, reducing their acute toxicity, while increasing their persistence. The release of sequestered QACs from soil can still potentially maintain concentration levels that are sufficient to develop antibiotic resistance in the environment.

Keywords Quaternary ammonium compounds . Quaternary alkylammonium compounds · Soil · Environment - Desinfectant use - Antibiotic resistance genes · Biocide susceptibility · QAC genes · Class 1

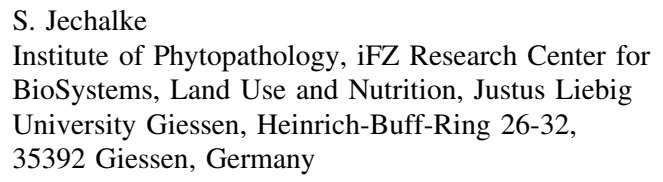


integrons · Clay minerals · Montmorillonite · Interlayer sorption

\section{Introduction}

The occurrence of multi-resistant pathogenic bacteria represents one of the pressing challenges of the twenty-first century and poses a major threat to human health. To inhibit the proliferation of antimicrobial resistant pathogens, a more prudent use of antibiotics is required in medical treatments. In the agricultural sector, the risks of selection and spreading of multidrug resistant pathogens can be alleviated by reducing the prophylactic use of antibiotics, as advised for pig farming (European Commission 2009). Similarly, the use of antibiotics for growth promotion has been banned in the EU since 2006. As in human healthcare, the agricultural sector must pay increased attention to hygiene to reduce the use of antibiotics. However, stricter hygiene standards often means an increased use of disinfectants, which in turn increases the risk of antimicrobial-resistant strain development (Walsh and Fanning 2008).

Among the most commonly used disinfectants are quaternary ammonium compounds (QACs). With a strong focus on wastewater and the aquatic environment, Zhang et al. (2015) recently reviewed the environmental occurrence of QACs including information on concentrations, fate, ecotoxicity, and analytical methods. Additionally, considerable amounts of QACs reach agricultural fields by the application of manures, sewage sludge or wastewater for nutrient recycling. Therefore, in this review we complement the work of Zhang et al. by summarizing current knowledge and research needs about the production, usage, detection, and environmental fate and effects of QACs. A special focus is put on the group of quaternary alkylammonium compounds (QAACs), their fate and their contribution to the development of antibiotic resistance in microbial communities in agricultural soils. Ultimately, we are paving the way to an agroecosystem-specific research hypothesis in which the interlayer regions of expandable 2:1 clay minerals act as significant sites for QAAC sequestration. The methodology for the applied literature survey is specified in Figure S1.
Fig. 1 Basic structural properties of the group of quarternary alkylammonium compounds. Each compound in pure form is present as a salt with accompanying $\mathrm{X}=$ halogen atom (or methylsulfate), that is not shown here for simplicity. a Linear alkylammonium-compounds, b imidazole compounds, c pyridinum compounds with $\mathrm{R}=$ alkyl chain. QACs of interest in this review belong to the group of linear alkylammonium compounds (QAAC), see (a) and bold box. $\mathbf{d}$ and $\mathbf{e}$ show examples of further QAC structures expected in the soil environment: d widely used herbicides and e naturally produced QACs detected in soil solution

\section{Structures and properties of QACs}

The acronym QAC is used to describe the entire group of quaternary ammonium compounds (corresponding to general structures a-c in Fig. 1; see also textbox in Figure S1). QACs comprise a quaternary nitrogen atom surrounded by four covalently bound organic moieties, whereby one permanent positive charge arises at the nitrogen atoms. Their charge is balanced by a counter ion, typically chloride or bromide, thus they exist as salts. Depending on the ternary amine employed during synthesis alkylation, QACs are differentiated into three main groups: (a) linear alkylammonium, (b) imidazole, and (c) pyridinium compounds (Fig. 1), each of which consists of numerous compounds and subgroups (Behler and Ansgar 2016). Contrary to amines (primary, secondary, ternary), QACs exhibit lower basicity and cannot be protonated. While (primary) amines are able to form up to three hydrogen bonds and surround themselves with a (first and second) hydration sphere, QACs are not hydrated hydrophilically, but rather act as water structure breakers (Yariv and Cross 2001). Soil-relevant examples of QACs, which are commonly not considered when addressing the surface-active and biocidal members of this group, are shown in Fig. 1d: diquat and paraquat, two QACs that are among the most widely used herbicides in the world and that have also been detected and retained in soil (Pateiro-Moure et al. 2013). Figure 1e displays an array of naturally produced QACs that may be encountered in soil solution and that can be taken up by plants (Warren 2013).

In this review, we will focus mainly on alkylammonium compounds, for which we suggest the abbreviation QAACs (quaternary alkylammonium compounds), corresponding only to structures shown 


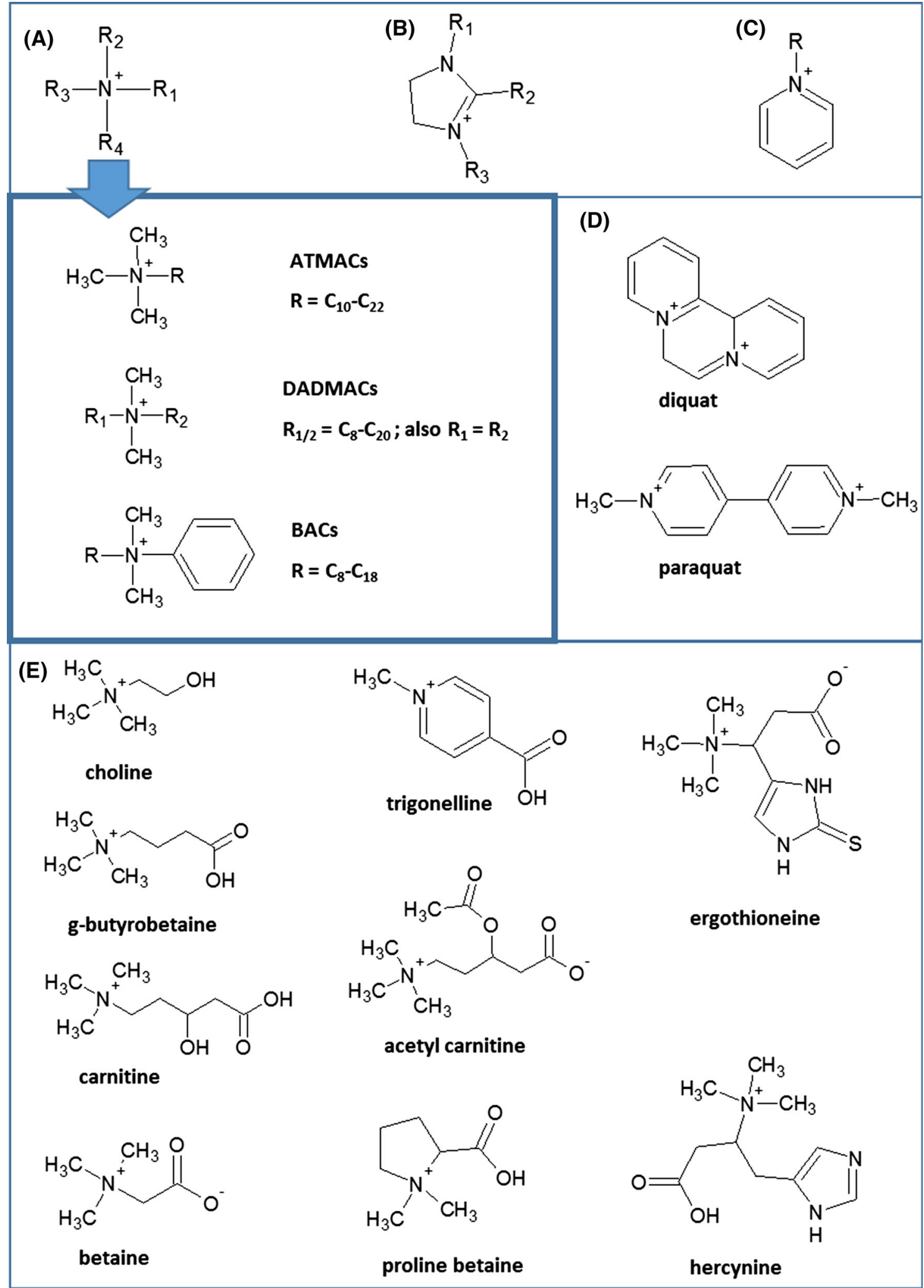




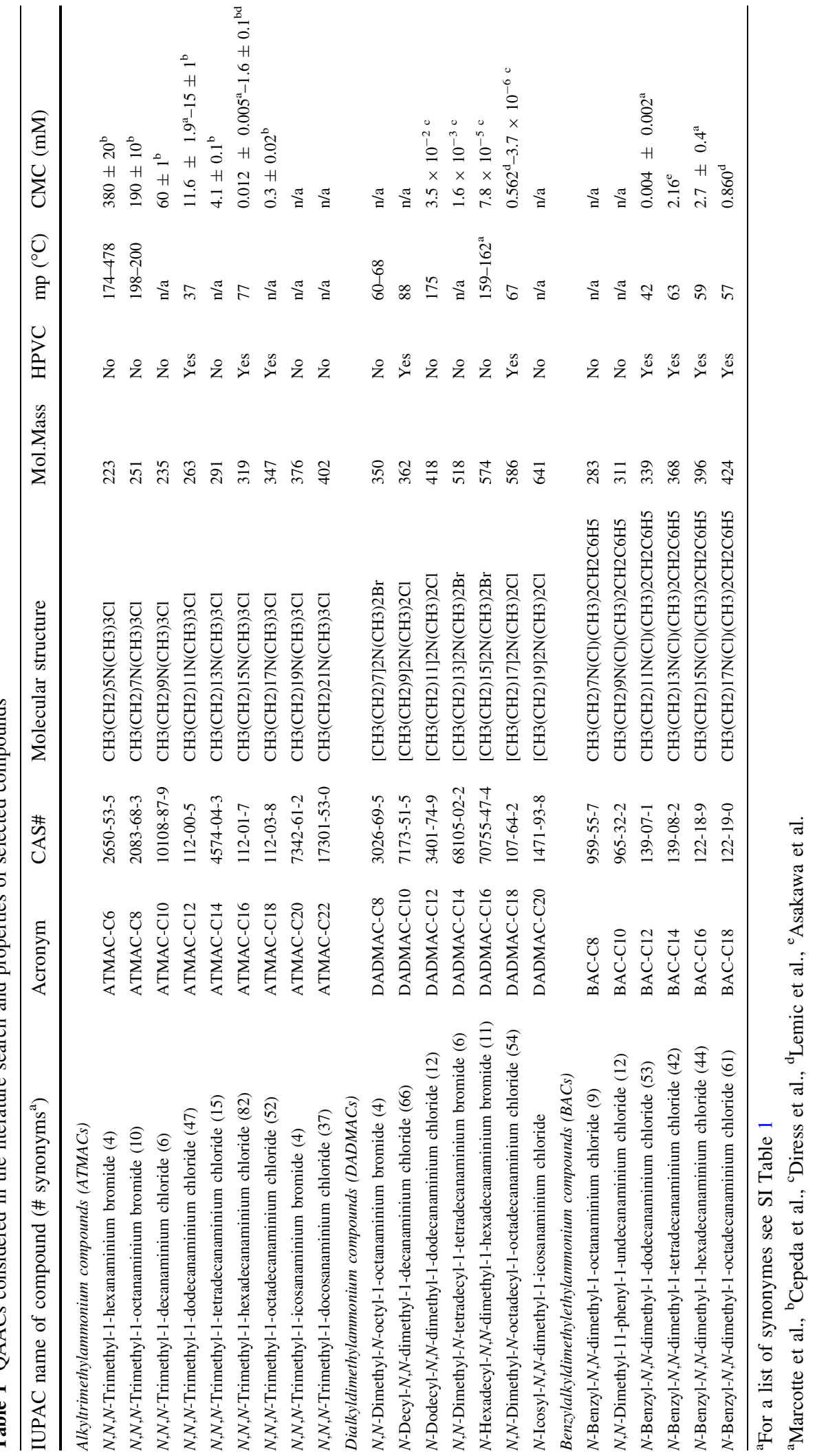


in Fig. 1a. The term QACs is applied only when no exact structures are reported, commonly reported in many QAC-resistance in molecular biology studies.

\section{Structures and properties of QAACs}

For homologues of the benzylammonium compounds (BACs), the cationic nitrogen is surrounded by a benzyl group, two methyl groups and one alkyl chain of chain length $\mathrm{C} 8-\mathrm{C} 18$. Highest biocidal activity is associated with $\mathrm{C} 12-\mathrm{C} 14$ homologues which are the main components in disinfection products (EURLSRM 2012).

Generally, QAACs tend to be soluble in water, but their solubility decreases with increasing chain length. Specifically, for dialkyldimethylammonium compounds (DADMACs) are freely soluble when bearing C8-chains at $8100 \mathrm{mg} \mathrm{L}^{-1}$, the $\mathrm{C} 18$ homologue possesses a solubility of only $2.7 \mathrm{mg} \mathrm{L}^{-1}$ (Boethling and Lynch 1992). Due to their amphiphilic nature, however, QAACs form micelles once their critical micelle concentration is reached (Table 1). This is a property not only affecting the efficiency of many surfactant-related applications, but also responsible for a dynamic equilibrium of surfactant molecules in micelles and surfactant molecules in cellular membranes that can result eventually in cell membrane dissolution, thus causing biocidal effects (Ishiguro et al. 2007). From Table 1, it is clear that alkyltrimethylammonium compounds (ATMAC) and DADMACs, show correlations exist between increasing hydrophobicity and decreasing critical micelle concentration. Table 1 also illustrates that data on $\mathrm{CMC}$ are incomplete and incoherent between authors as experimental setups vary (Asakawa et al. 2001; Lemić et al. 2005; Marcotte et al. 2005; Diress et al. 2007; Cepeda et al. 2013). Several studies have reported calculated values for the octanol-water partition coefficient for QAACs, although, these are not valid due to the surfactant nature of this compound class.

In summary, common features of the QAACs are that the combination of positive charge and hydrophobic alkyl chains and the resulting amphiphilic properties make them good surfactants and effective antimicrobial desinfectants. Their chemical structures promote electrostatic interactions with negatively charged surfaces, such as soil clay minerals or cell walls, at elevated $\mathrm{pH}$ also with soil organic matter or (hydr-)oxides.

\section{Use and production volumes of QAACs}

Being found in many disinfectants and surfactants, QAACs are used for a wide variety of purposes. They are employed as softener-active molecules in fabric softeners, to enhance thickening, foaming or wetting properties of surface cleaning agents, in laundry detergents, in personal care products, especially in hair conditioning due to the negative charge of hair cuticles to which they attach. Furthermore, QAACs are used in industry as debonding agents in paper production, for conveyor and chain lubricants and in road construction as adhesion promoters in bitumen emulsion. In oilfield applications, QAACs are, for example used as stabilizers for swelling clays, foaming, wetting, suspension properties and corrosion inhibitors, but they are also employed in the mining industry in mineral flotation separation processes (Steichen 2001; Kahrilas et al. 2015). For biostatic and biocidal applications, they are used in disinfectants and wood preservatives (Steichen 2001; Zabielska-Matejuk and Czaczyk 2006). In agriculture, QACs are used in pesticide formulations and they are common ingredients in disinfectants and detergents used in animal husbandry such as dairy cattle, hog, or poultry industries. The latter is exemplified in the list of disinfectants published by the German Society of Veterinary Medicine (DVG 2015). Noting, at least a quarter of the listed compounds contain QACs.

ATMACs are mainly used in hair care products, as conditioners, preservatives and personal care products, with $\mathrm{C} 14, \mathrm{C} 16$ and $\mathrm{C} 18$ alkyl chain lengths being the main ingredient in commercial products (LaraMartín et al. 2010). The extensive use of DTDMAC (mixture of DADMAC-C14-C18) in fabric softeners promoted concerns due to elevated concentration levels and aquatic toxicity measured in industrialized countries in the 1990s (Ruan et al. 2014). An ecological risk assessment initiated a voluntary phase-out by the industry and reduced their massive application in fabric softeners. Since then, more biodegradable diethyl-ester-dimethyl-ammoniumchlorides (DEEMDMAC) are employed as replacement compounds. Dialkyldimethylammonium with a C10 alkyl chain, also abbreviated DADMAC-C10, is 
today the main industrial component and makes up for more than $90 \%$ in industrial production (EURL-SRM 2012). BACs of various chain lengths have diverse applications ranging from surface disinfectants, for example in hospitals, food production, agriculture or dairy industry, to their use in eye drops and hair shampoos. BACs are also most often employed in technical mixtures of the $\mathrm{C} 8-\mathrm{C} 18$ homologues (mix registered under CAS\#63449-41-2). Highest biocidal activity is associated with $\mathrm{C} 12-\mathrm{C} 14$ homologues, which are the main component in disinfection products (EURL-SRM 2012).

QAACs reached special importance for the industrial preparation of so-called organoclays, which are used for thixotrophic fluids, in drilling fluids, as rheologic control agents in paint, cosmetics, refractory varnish, and adsorbents of organic pollutants in contaminated site remediation and in protective landfill liners. Organoclays are clay minerals whose surfaces are modified by organic compounds. For more details on organoclay production please refer to the excellent review by de Paiva et al. (2008). Montmorillonite, a dioctahedral smectite, used in organoclay preparation, is a mineral also typically encountered in soil environments. Therefore, interactions between this clay mineral and QAACs warrant specific consideration when addressing the fate of QAACs in the soil environment.

Contrasting the numerous reports on the uses of QAACs and QACs in general, production volumes and consumption data are more difficult to discern. Recently, a number of $700,000 \mathrm{Mg}$ year $^{-1}$ for QAC production has been cited by some authors (Tezel and Pavlostathis 2011; Jennings et al. 2015). However, in the original reference, this number referred to the amount of estimated annual consumption of cationic surfactants, which comprise both QACs/QAACs, but also include compounds of other substance classes. Another study reported that over 344,000 Mg (SI unit: megagram $=$ metric tons) QACs were produced annually in the US (Weston et al. 2000). In 1997, QAC consumption in Germany equaled $12,349 \mathrm{Mg}$ year $^{-1}$ by industry and $95.3 \mathrm{Mg}$ year $^{-1}$ used in hospitals. In Great Britain a total of 28,852 $\mathrm{Mg}$ year $^{-1}$ of QACs have been used in recent years (Sütterlin et al. 2008a, b).

Nevertheless, at least there are several homologues, which are used in such large quantities that they match the definition of so-called "High Production Volume
Chemicals" as listed by the Organization for Economic Co-operation and Development (OECD 2009) for chemical substances of annual production exceeding $1000 \mathrm{Mg}$ in at least one OECD member country. This definition was introduced by the OECD "in order to identify those which are potentially hazardous to the environment and/or to the health of the general public or worker" (OECD 2009). Table 1 indicates which of the homologues fall into this category-and this is in good agreement with the number of synonyms in use for the respective compound. Due to their widespread use QAACs, especially those classified as "High Production Volume Chemicals" will reach the soil environment (Fig. 2).

\section{Analytical methods used for QAAC analysis in environmental matrices}

Studies on fate and toxicity of QAACs in the environment are challenging due to their chemical properties and associated analytical difficulties. Until the mid-1980s QAACs have been determined colorimetrically after complexation with anionic-dyes. This method proved to be unsuitable for complex environmental matrices where anionic surfactants are also present (Boethling 1984). Scientific instrumentation and methods based on cation-exchange chromatography and thin-layer chromatography, GC/MS methods based on thermal decomposition and detection of Hofman degradation products, potentiometric determination with selective electrodes and infrared spectroscopic methods were increasingly replaced by high pressure liquid chromatography (HPLC) (Levsen et al. 1993). Fortunately, the extraction procedures for cationic compounds from sewage sludge have improved significantly. Traditionally, an extraction method with acidic methanol, followed by a timeconsuming sequence of liquid-liquid extraction has been employed traditionally (Wee 1984; Levsen et al. 1993; Gerike et al. 1994). Alternatively, supercritical fluid extraction has been used (Fernández et al. 1996). Solid-phase-microextraction (SPME) methods work well at concentrations below $2 \mathrm{mmol} \mathrm{L}^{-1}$ (Boyaci et al. 2014; Chen 2014), but are suitable only for batch sorption experiments or ecotoxicity tests due to the need of equilibration of the extraction fibers.

One major analytical challenge is the strong sorption to surfaces, which leads to difficulties in 


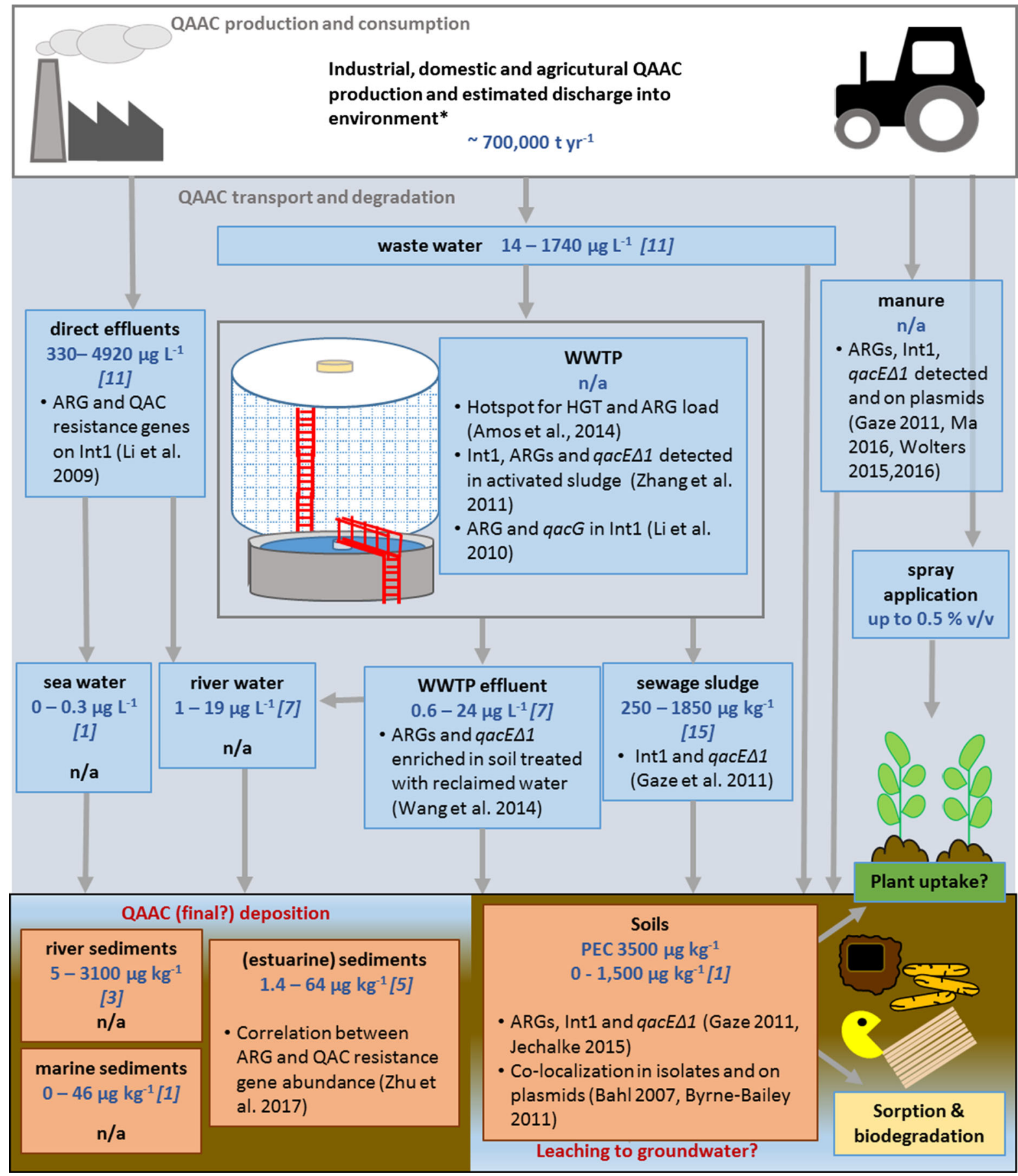

Fig. 2 Potential transport routes and observed concentrations of QACs in the environment. Environmentally observed summed QAAC concentrations are highlighted in blue. Numbers in brackets indicate number of available studies used as source for the summed QAAC concentration ranges (see also Table 2). Data not available is indicated (n/a). Examples for a co-selection potential of antibiotic resistance genes (ARGs) by co-localization or co-occurrence of class 1 integrons (Int1), plasmids and QAC resistance genes in environmental compartments are given. Calculation for predicted environmental concentration (PEC) is presented in Figure S2 of supporting information. (Color figure online) 


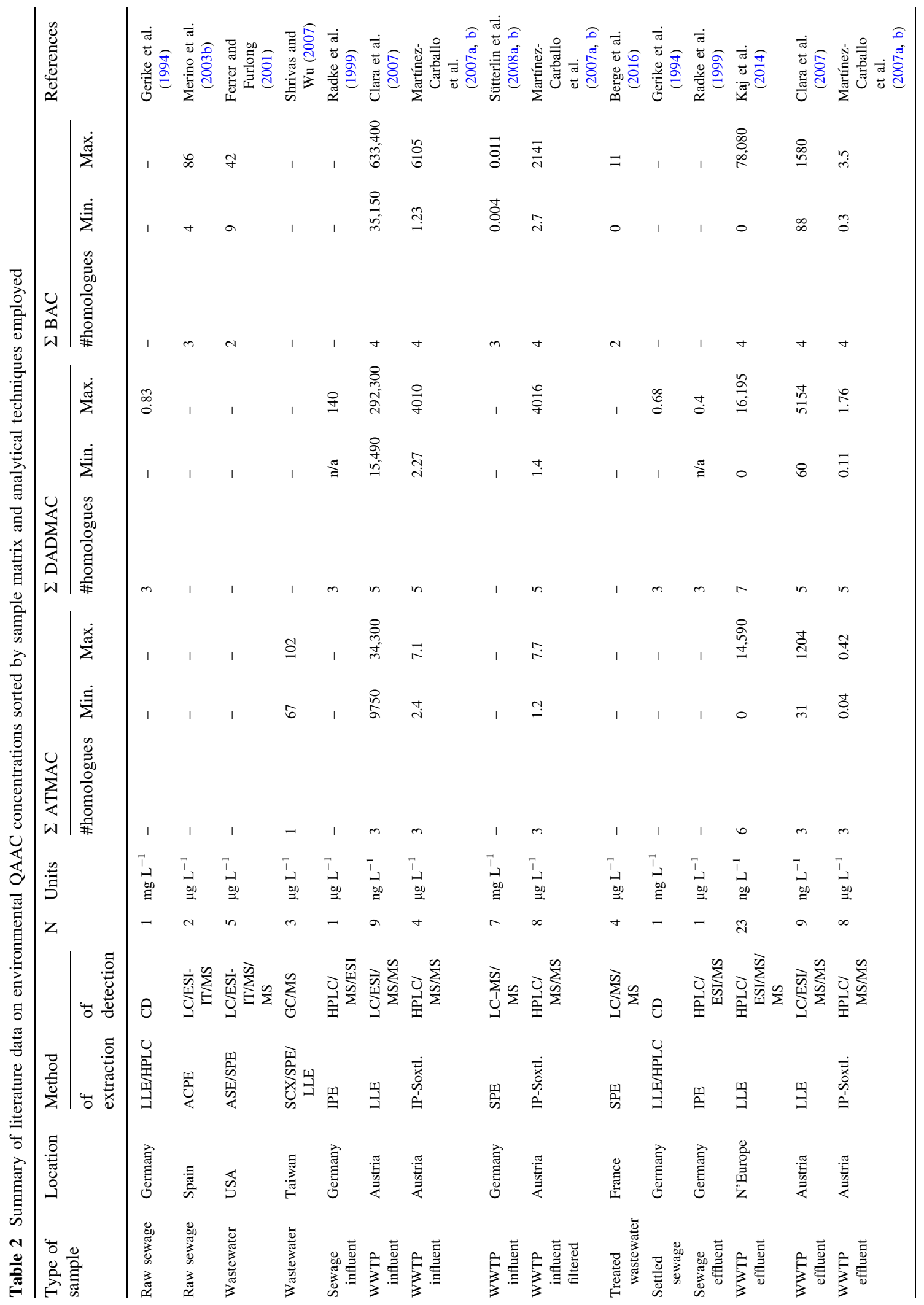




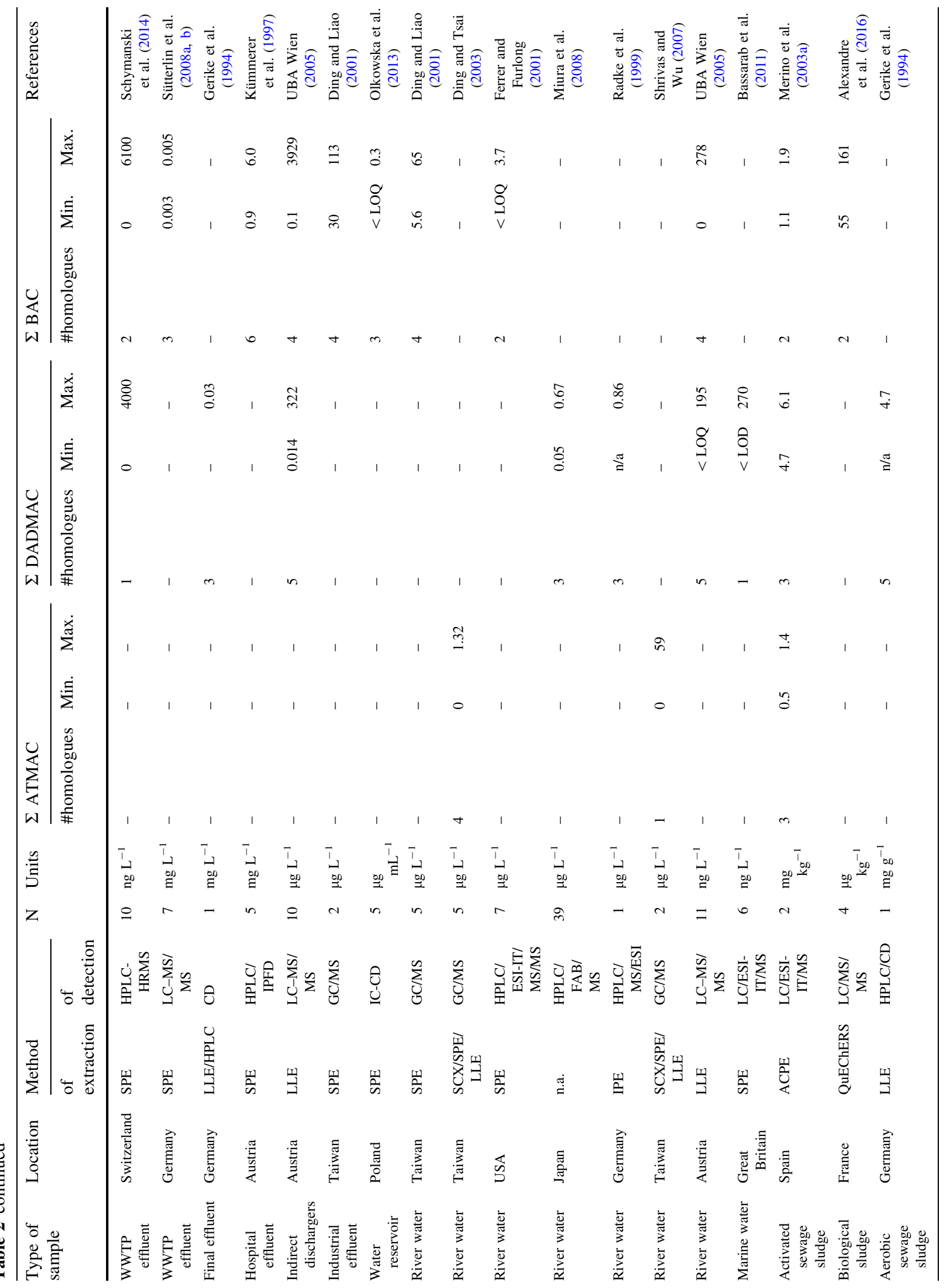




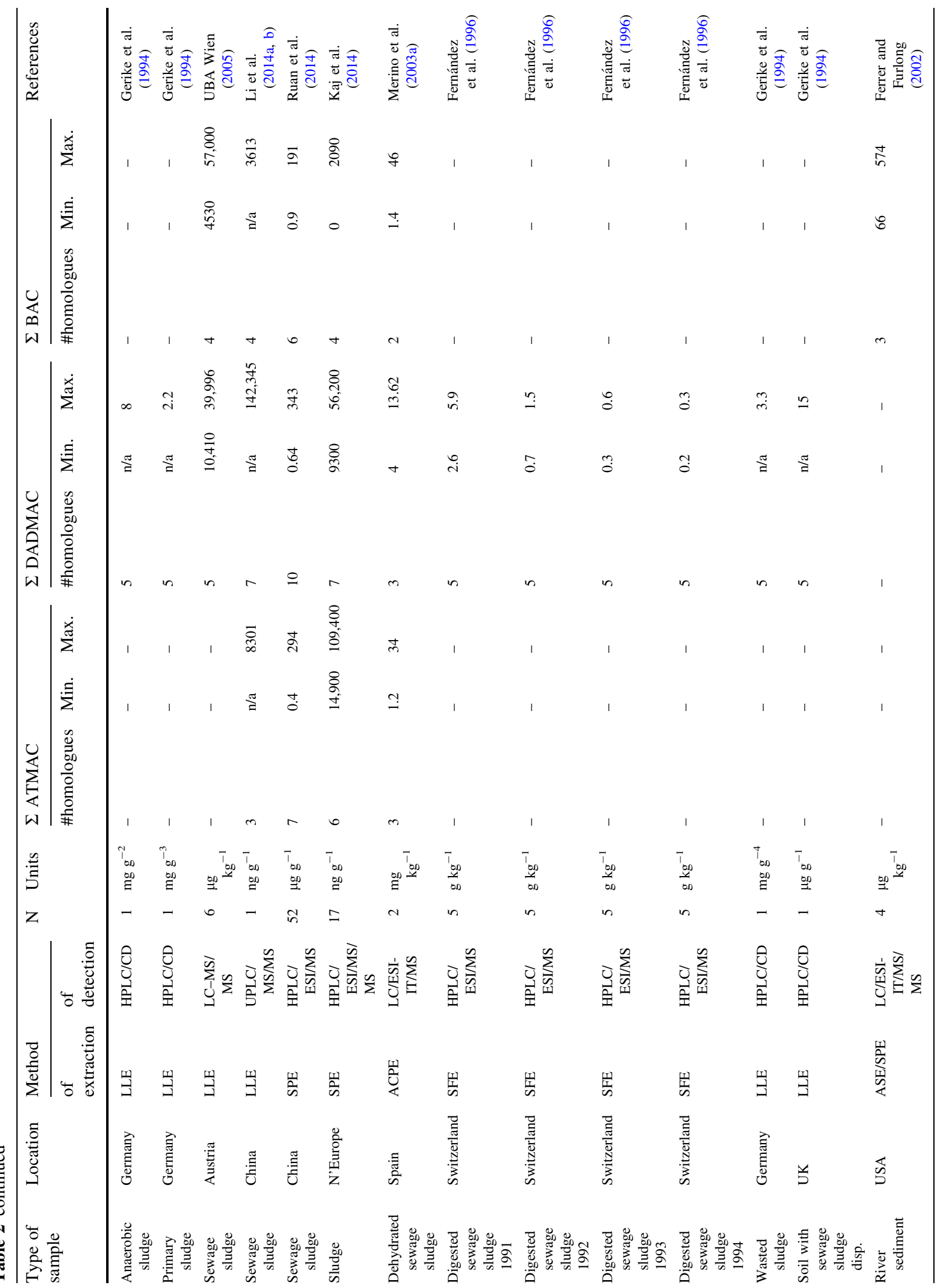




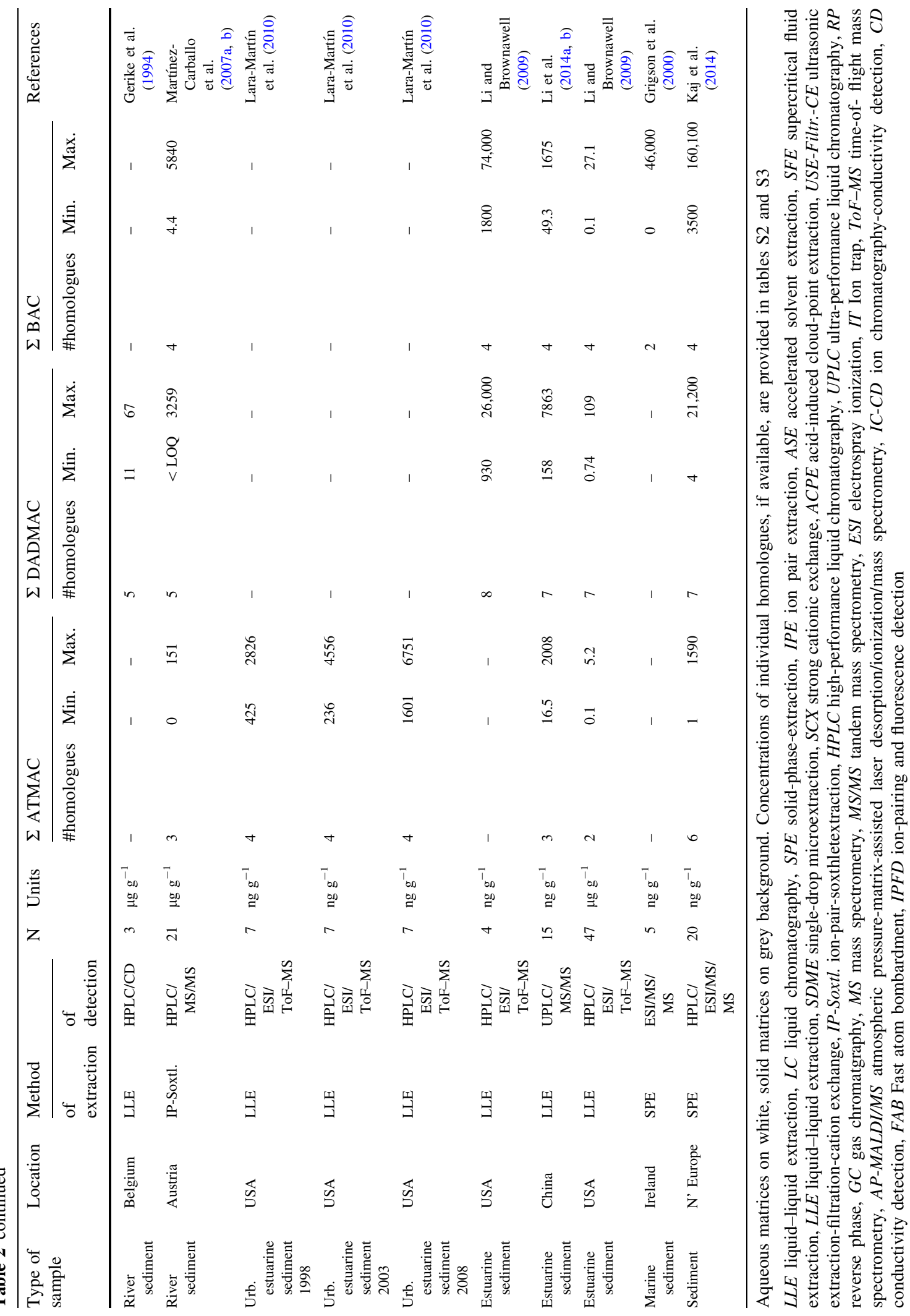




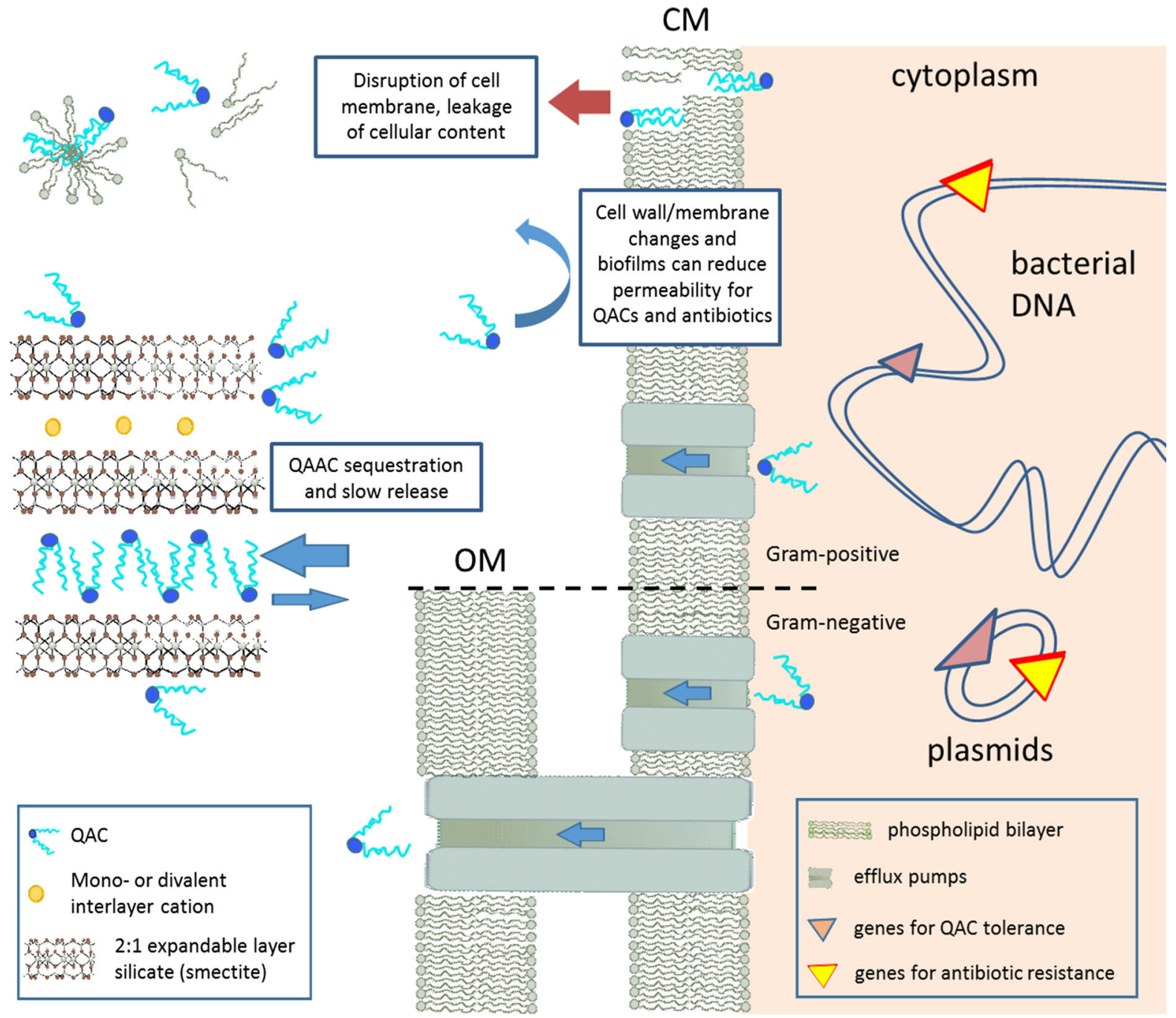

Fig. 3 Schematic view of QAC mode of action and QAC tolerance mechanisms in the presence of soil smectite. Smectite usually consists of 'packages' of stacked layers that reach a thickness of maximally $2 \mu \mathrm{m}$. The depicted layers have a basal spacing of 10-20 nm, depending on interlayer spacing. Via Adsorption of the positively charged QAACs to the negatively charged inner and outer surfaces of the clay mineral QAACs are sequestered and enriched in soils, leading to a reduced acute toxicity by free QAC monomers. Furthermore, QAACs may interact with anionic cell wall constituents such as lipopolysaccharides and teichoic acids. (Re-) mobilized QAACs may interact with the cell membrane and membrane proteins, cause

interpreting results, for example of studies on biodegradation. Chen (2014) provided systematic data on loss of analyte due to sorption to reaction vessels, caps and other materials used in solid phase extraction (SPE) and solid phase microextraction (SPME). The use of aluminum foil has been shown to reduce BAC- dissipation of the proton motive force and ultimately lead to leakage of cellular content and the death of the cell. Changes in permeability and biofilm formation can protect the cells from QACs. Energy-driven efflux pumps, encoded by genes located on the bacterial chromosome or plasmids can enhance the QAC tolerance. Besides biocides some efflux pumps are also known to be able to transport antibiotic compounds out of the cell. Colocalized antibiotic resistance genes on mobile genetic elements or within the same bacterial strain can further lead to coselection of antibiotic resistance by the presence of QACs. Outer membrane $(\mathrm{OM})$ and cytoplasmic membrane $(\mathrm{CM})$ are indicated

C12, BAC-16 and ATMAC-C16 losses to screw cap lids (Chen 2014).

Another obstacle for their analysis is that QAACs may form complexes with anionic compounds, such as anionic surfactants. As a consequence, they may be hardly detectable due to the altered hydrophobic 
nature of the complexes, depending on the analytical method that is employed (Boethling and Lynch 1992). Conversely, additions of diverse compounds as counter-anions during sample extraction have been documented to increase extraction efficiency and analytical response. Boyaci et al. (2014) used a zwitterionic detergent as matrix modifier in water samples. Others employed octadecylbenzenesulfonate (Ruan et al. 2014) or the detergent Marlon A375, a sodium alkylbenzenesulfonate (Martínez-Carballo et al. 2007a), for sewage sludge extraction as hydrophobic ion pair complexing agent. Chen (2014) found that trifluroacetic acid (TFA) added at $0.1 \%$ (volume) in methanol/water high pressure liquid chromatography (HPLC)- reduced peak tailing compared to the most widely used formiate, indicating better ion-pairing properties. Kang and Shin (2016a) found that perfluoroheptanoic acid yielded enhanced recoveries of BACs when added to the extraction of fortified soil samples.

For a compound-specific analysis of cationic surfactants, liquid chromatography with normal or reversed phase has been used in combination with conductivity detection as well as post-column ion-pair formation with phase separation and UV detection (Merino et al. 2003a). However, due to incomplete chromatographic separation of all homologues, electrospray tandem mass spectrometry (ESI-MS/MS) has been demonstrated to be a powerful and selective technique for the identification of individual QAACs and quantification of their concentrations in environmental samples, so that this technique is nowadays the dominant means of analysis (Ferrer and Furlong 2002; Martínez-Carballo et al. 2007a; Vidal et al. 2004; (Núñez et al. 2004; Li and Brownawell 2009). Although LC-MS/MS presents a convenient means of analyzing these non-volatile cationic surfactants with large molecular mass without further derivatization, exact concentrations of QAACs are still tricky to determine due to their surface-activity. Using MALDI-FTIR-MS, (Keller et al. 2008) identified DADMAC-C18, DADMAC-C16 and the mixed homologues DADMAC-C16-C18 as a contaminant with possible origin as catalyst or in personal care products in their article about interferences in modern mass spectrometry. Our own LC-MS/MS measurements as well as measurements in five other labs confirmed a background contamination with BAC-
C12 and DADMAC-C12, highlighting the ubiquitous occurrence due to the widespread use of QAACs.

Ultrasonic-assisted extraction procedures with acidic methanol have worked well for extractions from solid environmental matrices (Gerike et al. 1994; Martínez-Carballo et al. 2007a; Li and Brownawell 2009). For extractions procedures that need to be developed for soil sample screening, there are several recent multi-compound protocols for sewage-sludge available, which can serve as a point of reference (Martínez-Carballo et al. 2007a; Li and Brownawell 2009; Li et al. 2014a; Ruan et al. 2014). Ruan et al. (Ruan et al. 2014) reported lowest limits of quantitation between 1 and $4 \mathrm{ng} \mathrm{g}^{-1}$ and presented the most versatile method. They were able to quantify 23 QAAC homologues from Chinese sewage sludge.

In a very recent study, BACs were recovered from contaminated or spiked soil samples using a acetone:acetonitrile (1:1 vol:vol) ultrasonically assisted extraction procedure (Kang and Shin 2016a). More method development is needed, so that a standard analytical procedure for QAAC extraction from agricultural soils can be established. Accelerated solvent extraction could provide a good tool to reduce amounts of solvents used (Ferrer and Furlong 2002) and should also be explored for soils.

Overall, methods for environmental samples, especially concerning analyte extraction and separation, vary widely, much so, practically-to the extent that practically all studies on QAAC concentrations differ in analytical detail (see also Table 2). The development of a standard analytical protocol for sample screening especially of soil samples is currently lacking. For now, the method of choice is an ASESPE approach, employing an ion pairing agent for sample extraction and cleanup followed by HPLCtandem MS.

\section{Occurrence of QAACs in soil and environment}

Data for the production and consumption of QACs are scarce and scattered over many sources. Quantities of QACs found to contaminate the environment far exceed the amount of pharmaceuticals found by orders of magnitude. Since the use of QAACs is manifold, it is no surprise that QAACs were detected in considerable amounts in different environmental compartments, as visualized in Fig. 2. 


\subsection{Marine and freshwater environments}

Data for aqueous environments comprise data on surface water, usually river water, as well as one study on marine water, which was included in this data set (Ding and Liao 2001; Ferrer and Furlong 2002; Merino et al. 2003b; Ding and Tsai 2003; UBA Wien 2005; Shrivas and Wu 2007; Bassarab et al. 2011; Olkowska et al. 2013; Radke et al. 1999; Merino et al. 2003b). The overall mean and median values for QAAC cumulative concentrations for wastewater equal 271 and $11 \mu \mathrm{g} \mathrm{L}^{-1}$, respectively, and those for surface water equal 33 and $40 \mu \mathrm{g} \mathrm{L}^{-1}$, respectively. For ATMACs, mean and median concentrations of 10 and $8 \mu \mathrm{g} \mathrm{L}^{-1}$ for surface water even exceed the reported concentrations for wastewater. Rather than reflecting real world concentrations, these numbers illustrate the dilemma of study design. Most studies aimed to validate a method. Generally, water was sampled where it was supposed to contain some degree of QAAC contamination, so urban areas are over-represented compared to pristine environments.

\subsection{Wastewater systems}

Wastewater sums up influents as well as effluents and industrial discharges, and in some cases the line drawn between the indirect industrial discharge and river water sampled near wastewater inflow appears arbitrary. Therefore, each study is considered individually in Table 2 presenting cumulative values for individually determined DADMAC, ATMAC and BAC concentrations. Individual values for each homologue are provided in Tables S2 and S3 of the supporting information. Additionally, boxplots for cumulative concentrations are provided in Figure S3. Summed-up concentrations consist of different numbers of QAAC homologues (detailed values in SI Tables S2 and S3) Finally, the number of studies considered per sum parameter ranged from 2 to 14 (SI Figure S3).

The fate of QAACs in wastewater systems is documented in detail and was recently reviewed by Zhang et al. (Zhang et al. 2015). In wastewater treatment plants (WWTP), most surfactants are efficiently removed at average rates between 95 and $99 \%$ (Jackson et al. 2015). However, this removal is partly caused by sorption to sludge. Total QAAC concentrations determined in the eight available studies on sewage sludge reach the $\mathrm{mg} \mathrm{kg}^{-1}$ level (Gerike et al.
1994; Fernández et al. 1996; Merino et al. 2003b; UBA Wien 2005; Martínez-Carballo et al. 2007b; Kaj et al. 2014; Li et al. 2014b; Ruan et al. 2014) with a median of $59 \mathrm{mg} \mathrm{kg}^{-1}$ and a mean of $220 \mathrm{mg} \mathrm{kg}^{-1}$ (SI Figure S3). The maximum content reported was $8 \mathrm{~g} \mathrm{~kg}^{-1}$ for DTDMAC (DADMAC-C14-C18) in an anaerobic sludge (Gerike et al. 1994) but this concentration should be considered with caution due to the colorimetric detection procedure as disulfine blue complexes form and likely a result in overestimation.

\subsection{Sediments}

Total QAAC concentrations in sediments can only be estimated, as data are compiled from studies of different authors, methods and QAAC homologues detected (Gerike et al. 1994; Fernández et al. 1996; Grigson et al. 2000; Ferrer and Furlong 2001; Merino et al. 2003b; UBA Wien 2005; Lara-Martín et al. 2010; Li and Brownawell 2010; Kaj et al. 2014; Li et al. 2014b; Ruan et al. 2014; Alexandre et al. 2016). The data we report do not represent results from systematic screening, and standard methods do not exist. Nevertheless, published data indicate a significant accumulation of QAACs in the order of $0.1-100 \mathrm{mg} \mathrm{kg}^{-1}$ in sediments of rivers and estuaries. Values for DTDMAC can exceed $25 \mathrm{mg} \mathrm{kg}^{-1}$, according to Jackson et al. (2015). Li and Brownawell (2009) found that concentrations of QAACs of up to $74 \mathrm{mg} \mathrm{kg}^{-1}$ in sewage-impacted estuarine sediments were larger than concentrations of other organic contaminants measured in the same or nearby samples. In their review addressing 'emerging' organic contaminants in biosolids for their agricultural application, Clarke and Smith (2011) showed that QAAC concentrations rank 4 th in the upper $\mu \mathrm{g} \mathrm{kg}^{-1}$-range, which is in agreement with the literature data, and one order of magnitude larger than concentrations encountered for pharmaceuticals in biosolids. For more detail on QAAC concentrations in sewage, sludge, surface water and sediments, please refer to Tables S2 and S3 in SI.

\subsection{Soils}

The abovementioned studies document a high potential for QAACs to accumulate in sediments after they are released into rivers or marine waters, even if the latter QAAC concentrations are below critical levels. 
Also, it seems likely that also other ecosystems exposed to QAAC sources will show an enrichment of these compounds. In this regard, particularly agricultural soils that receive organic fertilizers or wastewater for nutrient and water recycling might be exposed to considerable amounts of QAACs. Nevertheless, the fate and transport of QAACs in soils are not well documented. Monitoring data on background concentrations of QAACs in different soils are practically not available. The application of manure, sewage sludge, wastewater, as well as their prophylactic use as biocides as well as adjuvants in agricultural pesticide formulations represent the main input pathways of QAACs in agricultural soils. Pesticide formulations contain QAACs as adjuvants particularly if the agents are not soluble in water. In this case, QAACs help to enhance their solubility, to improve rainfastness and facilitate their penetration into leaves. Tezel (2009) provided consumption data for the biocidal adjuvants BAC-C12-16, DADMAC-C10, DADMAC-C8-10 and DADMAC-C8 in the State of California (USA), summing up to about $5000 \mathrm{~kg}$ in 1 year. Typical QAC concentrations in agrochemical tank-mixed sprays range from 0.05 to $0.5 \% \mathrm{v} / \mathrm{v}$ (Steichen 2001).

Based on personal communication with local hog farmers and product information on disinfectants used before restocking, an estimate for the concentration of the compound DADMAC-C10 in manure was in the $\mathrm{mg} \mathrm{kg}^{-1}$ range. Predicted QAAC concentrations of up to $3.65 \mathrm{mg} \mathrm{kg}^{-1}$ could be reached in agricultural soil based on inputs with manure during 1 year, assuming zero biodegradation due to strong sorption and effective sequestration (detailed calculation in SI Figure S2).

QAACs may reach soils also via the land disposal of sewage sludge. Assuming that sewage sludge is applied at a rate of $5 \mathrm{Mg}$ per hectare to agricultural fields every 3 years according to the German Sewage Sludge Regulation AbfKläV §6(1), agricultural soils receiving sewage sludge may contain levels of QAACs in the upper $\mu \mathrm{g} \mathrm{kg}^{-1}$ to $\mathrm{mg} \mathrm{kg}^{-1}$ range (SI Figures S3 and S2).

In a recent study, Kang and Shin (Kang and Shin 2016b) extracted BAC homologues of carbon chain length 8-18 (Fig. 1a) from Korean soils that were "covered with disinfectants including BAC from November 2013 to February 2014". Although the authors did not provide more details on the nature of the contamination with BACs or the types of soil exposed, their study showed that BACs were retained by soils as the compounds were detected in the low $\mathrm{mg} \mathrm{kg}^{-1}$ concentration range in soil samples taken half a year after coverage. Largest concentrations were reported for BAC-C12 and BAC-C14. The only other data point for soil is a reported DTDMAC concentration of $15 \mathrm{mg} \mathrm{kg}^{-1}$ for a soil to which sewage sludge has previously been amended (Gerike et al. 1994). Hence, both studies provide evidence that soils do have the capacity to store QAAC over time. More research is needed to ascertain QAAC occurrence and concentrations in agricultural soils. When screening soil for QAACs, attention should be paid to emerging compounds such as ATMAC homologues of chain length C20-C24 (Ruan et al. 2014), dipalmitoylethyl hydroxyethylmonium methosulfate, a HPV chemical with the commercial name stephanquat GA90 (Alexandre et al. 2016), and pyridinium compounds such as dodecyldyridinium chloride (Marcotte et al. 2005).

\section{Persistence of QAACs in soil}

Biodegradation controls QAAC dissipation in the environment. The process has been reviewed elsewhere (Ying 2006; Zhang et al. 2015; Jardak et al. 2016) and therefore only a brief summary is given here. Generally, QAACs may be utilized by microorganisms as a source of carbon and energy (Ivankovic and Hrenovic 2010; Jardak et al. 2016). However, while under aerobic conditions the biodegradation typically decreases with the number of non-methyl alkyl groups attached to the quaternary nitrogen, little if any biodegradation was observed under anaerobic conditions. Heterogeneous testing conditions for the biodegradability of QAACs often make it difficult to differentiate between proportions adsorbed and in fact degraded (van Ginkel and Kolvenbach 1991; Tezel et al. 2006). Overall, it can be stated with relative certainty that QAACs are not well or not at all degraded under anaerobic conditions, therefore, tend to accumulate under anaerobic conditions (Garcĺa et al. 2000; Ying 2006; Zhang et al. 2011a). Under aerobic conditions degradation is faster. Enzymatic biotransformation by amine oxidase was reported for BAC at $20 \mathrm{nmol} \mathrm{mg} \mathrm{protein}{ }^{-1} \mathrm{~min}^{-1}$ (Ertekin et al. 2016) and QAAC half-lives were on the order of hours 
(Tezel et al. 2012). However, due to adsorption processes even aerobic biodegradation is often incomplete or significantly slowed down (Fenger et al. 1973; Boethling 1984; Tezel et al. 2006) and overall rather poor (Hegstad et al. 2010a), likely due to sorption processes reducing the bioaccessibility of QAACs. Usually, a portion of the total concentration of a pollutant in soil may be taken up by microorganisms, commonly equated with the so-called bioavailable or bioaccessible fraction (Semple et al. 2004; Hatzinger and Alexander 1995; Jechalke et al. 2014). This fraction declines usually much faster with time than the total concentration of a pollutant in soil. The remaining part may be reversibly sequestered in soil if not even forming irreversibly bound residues, as, e.g. shown for antibiotics (Förster et al. 2008; Zarfl et al. 2009) and a range of pesticides (Calderbank 1989; Laabs et al. 2002).

\subsection{QAAC sorption and sequestration in soil}

Sequestration includes all processes that reduce the bioavailability and bioaccessibility of a compound in soil. To understand which portion of QAACs may potentially be sequestered, we need to understand their sorption and binding mechanisms. For soils, an understanding of sorption processes is of utmost importance as these processes will determine QAAC bioaccessibility, acute toxicity, and long-term persistence (Tezel 2009; Clarke and Smith 2011).

From the preparation of organoclays it is known that QAACs can be sorbed into the interlayers of clay minerals via ion exchange and van der Waals interactions in mono-, di-, pseudotriple or paraffin type layers causing an expansion of the basal spacing; this has been confirmed using X-ray diffraction (de Paiva et al. 2008). High sorption affinity of QAAC in organoclay preparation indicates a potentially important role of the most commonly employed smectite minerals, which are likewise typical soil minerals.

The structure of smectites, which belong to the phyllosilicates, also termed layer- or sheet-silicate, is closely related to that of the minerals mica and vermiculite. Smectites belong to the group of 2:1 layer silicates, meaning that one octahedral sheet is sandwiched in between two opposing tetrahedral sheets, together making up one layer. Their permanent negative layer charge ranges from 0.2 to 0.6 charge units per formula unit depending on the degree of isomorphic substitution (Bailey 1980). These charges are usually balanced by interlayer cations, as shown for the example of a smectite structure in Fig. 3. Depending on intercalated cations and their hydration energies, the basal spacing of crystal layers ranges from 1.35 to about $2 \mathrm{~nm}$. The cation exchange capacity is generally understood to be equivalent to the layer charge and ranges from 47 to $162 \mathrm{cmol}_{\mathrm{c}}$ $\mathrm{kg}^{-1}$ (Borchart 1989). Cationic organic molecules may replace the inorganic exchangeable cations while non-ionic polar molecules may replace water that was adsorbed to the siloxane surfaces of the clay mineral (Deng and Dixon 2002; Brigatti et al. 2006).

Besides smectites, potential adsorbents in soils also include other clay minerals, soil organic matter (SOM), oxides, proteins and microbial cell walls. Decisive for the type and relevance of the different sorption mechanisms are the specific molecular structure and concentration of the QAACs, as well as the nature of sorbents present. For simple cationic QAACs (Fig. 1a-d), and at low QAAC loading of sorbents, ion exchange is the dominant sorption mechanism. For example, Chen et al. (2012) demonstrated for BAC$\mathrm{C} 12$ sorption to purified humic acid. The sorption coefficient decreased with increasing ionic strength of $\mathrm{Na}^{+}$and $\mathrm{Ca}^{2+}$ background solutions due to competitive sorption with other cations. At elevated concentrations that are still below the critical micelle concentration, multiple adsorption layers can form on the sorbate surface. The hydrophobic interactions occur with alkyl chains of QACs that are already adsorbed via ion exchange (Sánchez-Martín et al. 2008; Ying 2006; Ismail et al. 2010).

For QAACs, more than one sorption mechanism is conceivable. First, via their ionic and hydrophilic part, i.e. the nitrogen cation. QAACs are capable of cationic exchange or electrostatic attraction to negatively charged sorbate surfaces. They are also able to form ion pairs with anionic surfactants or other organic molecules. The alkyl chain-dominated part of the molecule is responsible for sorption based on hydrophobic forces which lead to sorption to hydrophobic areas of soil organic matter (SOM) (Ren et al. 2011). In this regard, the length of alkyl chains is a crucial parameter that determines the affinity of the compounds to organic matter. In one sorption study with sewage sludge, Ismail et al. (2010) found that QAACs with a longer alkyl chain sorb stronger than QAACs with a shorter alkyl chain. This 
was in good correspondence with increased hydrophobic interactions with hydrophobic organic matter moieties. The benzyl group further enhanced the sorption of QAACs, but this effect diminished with increasing alkyl chain length.

In most studies, $\mathrm{K}_{\mathrm{d}}$ and $\mathrm{K}_{\mathrm{oc}}$ partition coefficients were given. In some cases, Langmuir and Freundlich sorption coefficients were determined. For BAC-C12 sorption to humic acid, Chen et al. (2013) reported a decrease of the $\log \mathrm{K}$ value by two orders of magnitude, from about 4 to 2 , due to increasing competition with $\mathrm{H}^{+}$under acidic conditions. Further data on $\mathrm{pH}$ dependency of QAAC sorption are scarce. With $\log \mathrm{K}_{\mathrm{oc}}$-values ranging from 4.7 to 6.2 $\left(\log \mathrm{L} \mathrm{kg}^{-1}\right.$ ), DADMAC-homologues show slightly larger $\log \mathrm{K}_{\mathrm{oc}}$ values than BAC homologues. Interestingly, data from Ren et al. (2011), Juergensen et al. (2000) and Wang and Keller (2008) show increasing sorption of the corresponding QAAC compound with decreasing particle size of the sorbent. This would be in good agreement with increasing surface areas of clay mineral surfaces present in smaller size fractions, if sorption to oxide surfaces can be neglected at common soil $\mathrm{pH}$ values.

However, for QAACs the meaningfulness of $\log$ $\mathrm{K}_{\mathrm{oc}}$ and especially (calculated) $\log \mathrm{K}_{\mathrm{ow}}$ values is highly questionable (van Wijk et al. 2009) due to their surfactant properties and tendency to accumulate at phase boundaries instead of partitioning into the one or the other phase. In a study on BAC-C12 and BAC-C14 sorption to montmorillonite, Zanini et al. (2013) confirmed suggestions from Chen et al. (2013) for sorption to humic acid with small QAAC concentrations stating that cation exchange is the main adsorption mechanism with very similar binding constants for both surfactants. At elevated concentrations they noted a sharp increase of sorption past an infliction point (S-shaped isotherm), and they attributed this finding mainly to interactions between BAC surfactant molecules. The application of the classical Langmuir equation in this case, spanning a QAAC concentration range of several orders of magnitude ( $1 \mathrm{nM}$ to $10 \mathrm{mM}$ ), would not be possible, as only one step would be predicted. Therefore, Zanini et al. (2013) employed a Langmuir isotherm with two terms. The second $\log \mathrm{K}_{\mathrm{L}}$ values were clearly larger for BAC-C14 than for BAC-C12, -0.46 and 1.32 , respectively. This increase of sorption at elevated concentrations was more intense for BAC-C14 than for BAC-C12 as expected from the increasing alkyl chain length. Zanini et al. (2013) calculated that in natural systems and for small BAC input concentrations of $<0.7 \mathrm{mg}$ $\mathrm{L}^{-1}$, such as those expected under most conditions in soils, silicate clays are major sorbents for BAC, while binding to SOM is more relevant at larger QAAC concentrations. According to Zanini et al. (2013), it is unlikely that iron oxides play a major role for QAAC binding in soils. Further data on the role of oxides in QAAC binding are lacking so far.

Droge and Goss (2013a) investigated sorption of a broad range of organic cations to phyllosilicate clay minerals and identified a need of developing validated sorption models for organic cations at trace-concentrations. Within the group of cationic organic compounds, Droge and Goss (2013b) found that QAACs had a clearly larger affinity to clay minerals than to SOM. Smectite showed up to $1.4 \mathrm{log}$ units larger sorption coefficient for QAC than did kaolinite and illite, thus demonstrating that QAC sorption in soils may be strongly influenced by smectite-rich clay fractions. However, the experiments made by Droge and Goss (2013b) addressed the influence of a wide range of structural variations of organic cations on their sorption to phyllosilicate clays, and only one QAAC (ATMAC-C8) of the homologues commonly observed in environmental samples was included in their large set of samples. In sorption studies with ATMAC-C12, Xiang et al. (2016) confirmed an increased sorption for this compound with increasing soil clay and potassium content. Zanini et al. (2013) and $\mathrm{Xu}$ and Boyd (1995) investigated the movement of BAC and ATMAC-C16 into the interlayers of montmorillonite using $\mathrm{x}$-ray diffraction. An interlayer expansion from $1.2 \mathrm{~nm}$ to $1.8 \mathrm{~nm}$ was determined, while the largest expansion was measured when the saturation of the clay's cation exchange capacity of $0.764 \mathrm{mmol} \mathrm{g}^{-1}$ was reached or surpassed. In industrial organoclay production, where large concentrations of QAC are employed to modify smectite surfaces, expansion of interlayer distances of up to $2.7 \mathrm{~nm}$ was determined (de Paiva et al. 2008), and the arrangement of ATMAC and DADMAC in mono-, biand pseudo-triple layers within expandable clays is also known (Jasmund and Lagaly 1993; Ruiz-Hitzky and Van Meerbeek 2006). In the context of remediation of soils contaminated with hydrophobic organic compounds, several studies reported expansion of the $\mathrm{d} 001$ basal spacing of smectites by QACs up to $2.1 \mathrm{~nm}$ 
Box 1 Outstanding questions and research needs

Data on QAAC concentrations in soil are practically not available

Are QAAC concentrations in soil elevated by irrigation with wastewater or amendment with manure and biosolids?

Do QAACs accumulate in soil over time?

What are the bioavailability, acute toxicity and long-term persistence of QAACs in soil?

Does the soil clay mineralogy determine the long-term fate of QAACs?

Does QAAC adsorption into interlayers of smectite prevent QAAC-biodegradation?

How does variation in interlayer cation or octahedral and tetrahedral composition of smectite influence their QAAC adsorption capacity?

Which conditions would favor a release of QAACs from smectites to soil solution?

Does the QAAC sequestration buffer acute toxicity to soil microorganisms to a sub-inhibitory level?

Do QAACs in soils promote in situ decrease of biocide suscepitbility development and spread?

Are QAC resistance mechanisms in soils influenced by naturally occurring QAACs?

Is a decrease in QAC biocide suscepitibility favored in the presence of 2:1 clay minerals?

Are some QAAC homologues more "resistance-gene-selecting" than others?

Is the pollution of the soil environment by QAACs contributing to the increasing threat of multi-resistant human pathogens and to which extent?

(Koh and Dixon 2001; Klapyta et al. 2001; Zhu et al. 2003; Martin-Sanchez et al. 2012): Therefore, it seems likely that intercalation of QAACs into the interlayers of clay minerals is one main endpoint of QAAC sequestration in soils, probably contributing to the socalled pool of non-extractable residues which to our knowledge has not yet been assessed for these compounds.

It should be noted that the cited works can serve as a reference point illustrating the possibility of QAACs entering interlayers of clay minerals, but they do not necessarily contribute to an understanding of the sorption and fate of QAACs in soils under real field conditions. Many clay minerals in soil are covered by patchy surfaces with SOM and oxides (Mayer 1999; Mödl et al. 2007; Kaiser and Guggenberger 2007); frequently they are involved in the formation of microaggregates (Totsche et al. 2017), and cations may block intercalation if not replaced by high QAAC contents. In addition, long-term applications of manure or sewage sludge, or irrigation with wastewater form conditions different to those studied in the lab or with pure compounds. The influence of competing ions or co-adsorption phenomena of other organic or heavy metal pollutants were not yet subject of study. Nevertheless, anion transport properties of organoclays are well documented and used in engineered barriers. A modification of clay-sorbent properties with increased QAAC loading such as surface charge, wettability and diffusivity can be expected and this has, for example, been demonstrated for hexadecylpyridinium montmorillonite (Schampera and Dultz 2011).

In summary, due to their negative charge and high sorption affinity, expandable layer silicate minerals in soils have at least the potential to sequester a significant portion of QAACs into their interlayers as schematically displayed in Fig. 3. Acute QAAC toxicity to the soil microbial community would be buffered as a result and may cause continuous exposure of soil microorganisms to sub-inhibitory concentrations of QAAC. Future research must now determine to what degree QAACs are: entering the soil, remain mobile to reach clay interlayers, and exchange interlayer cations. In addition, future work must also address the role of oxides and microaggregation for QAAC sequestration in soils.

\subsection{Effects of QAACs on the soil microbial community}

The composition and function of soil microbial communities maybe affected by not sequestered QAACs loosely attached to surfaces by equilibrium sorption and directly available in soil solution. In general, QAACs exert antimicrobial activity against gram-positive and gram-negative bacteria mainly by an interaction with the phospholipids and proteins of 
cell membranes and the disruption of membrane integrity, resulting in a leakage of cellular content (Gilbert and Moore 2005; Ioannou et al. 2007; Bragg et al. 2014). Usually Gram-positive bacteria are more susceptible to QAACs than Gram-negative bacteria due to the lack of the outer membrane, while QAACs are not lethal to bacterial spores and mycobacteria (White and McDermott 2001; Hegstad et al. 2010a).

To our knowledge, studies quantifying the bioavailable or bioaccessible fractions of QAACs in soil are still lacking. It seems reasonable to assume that in soils rich in 2:1 layered clay minerals and other active sorbents, the bioavailable fraction will be smaller than in sandy soils, which are poor in organic matter contents, for instance. In addition, it seems likely that the bioavailability of QAACs depends on their chemical structure. As biodegradability of QAACs (see above) decreases and sorption increases with increasing chain length, as demonstrated for sludge (Clara et al. 2007), smaller QAACs are likely more prone to exert acute toxicity effects on soil microorganisms than larger ones, which likely persist longer in soil and are thus more prone to exert chronic toxic effects. So far, no such differentiation could be made in the very few pioneering studies on the fate and effects of QAACs in soil.

For anaerobic digestion processes, several studies report an adverse impact of QAACs on methanogenesis and biogas production (Zhang et al. 2015). However, detailed knowledge of the effects of QAACs in soil on microbial processes and activity, however, is scarce. In a microbial bioassay using Nitrosomonas communis as the test organism, the effect of benzalkonium chloride on the nitrification in pasture soil from Germany was determined as an indicator of metabolic activity. The $\mathrm{EC}_{50}$ value was calculated to be $221 \mathrm{mg} \mathrm{kg}^{-1}$ soil (Frühling et al. 2001). A similar study using samples of a Luvisol obtained an $\mathrm{EC}_{50}$ of $500 \mathrm{mg} \mathrm{kg}^{-1}$ for the effect of BAC on the dehydrogenase activity of Bacillus cereus, while a concentration of more than $1 \mathrm{~g} \mathrm{~kg}^{-1}$ completely inhibited the dehydrogenase activity (Ronnpagel et al. 1995). In another soil study using a fine-loamy agricultural soil as well as fine-grained aquifer sediment, QAAC treatment increased lag periods while decreasing the rate and extent of mineralization of test compounds (Nye et al. 1994). Sarkar et al.(2010) found negative effects of ATMAC-C16, ATMAC-C18 and Arquad (compound not specified by the authors, refer also to list of synonyms in SI) on enzyme activity, dehydrogenase and potential nitrification activities at concentrations of 50 to $750 \mathrm{mg} \mathrm{kg}^{-1}$ soil. However, the authors described that small concentrations of QAACs could enhance the dehydrogenase activity and potential nitrification in some soils, and that the effects of QAACs were variable in the three different soils studied, which was related to differences in soil properties. Especially the organic carbon content influenced the QAAC bioavailability.

In studies with artificial soils, it was demonstrated that the type of clay mineral present influences the microbial community composition. Therefore, the communities responded differently to the spiking of organic amendments (Ding et al. 2013; Babin et al. 2013, 2014; Pronk et al. 2017). This suggests that expandable layer silicate minerals might therefore influence the effects of QAACs in soil not only by sequestration of the compound (Fig. 2), but also by shaping the associated microbial community composition.

The presence of QAACs can lead to an increased tolerance of bacteria expressed in minimum inhibitory concentration (MIC) increases and a reduced susceptibility. A total bacterial resistance against QACs is unlikely due to their nonspecific action (Weber and Rutala 2006; Maillard 2007; Bragg et al. 2014; Gerba 2015; Jaglic and Cervinkova 2012). Bacteria with a significant increase in MICs against QAACs, however, might still be susceptible to commonly applied concentrations of biocides. Therefore, the determination of minimum bactericidal concentrations (MBCs), allowing the comparison of lethality between standard and resistant strains, was suggested to be more appropriate than the determination of MICs (European Commission 2009).

\subsection{Role of QAACs in the selection of antibiotic resistance}

There is growing evidence that the use of QAACs as biocides against microorganisms can lead not only to reduced biocide effectiveness, but also increase the resistance towards antibiotic agents over time (Weber and Rutala 2006; European Commission 2009; Andersson and Hughes 2012; Singer et al. 2016). This can, for example, be caused by an increased expression of energy-driven drug efflux systems such as the AcrAB pump or the NorA and MdeA multidrug efflux systems 
that can extrude QACs as well as multiple antibiotics (Levy 2002; Poole 2005; Hegstad et al. 2010b). Various qac genes have been described, which are widely spread among clinical and environmental bacteria and code for energy-dependent efflux pumps targeting a wide range of more than 30 lipophilic cationic compounds from at least 12 different chemical classes (Jaglic and Cervinkova 2012). Furthermore, for $q a c C$ it was shown that it confers resistance to a number of $\beta$-lactam antibiotics (Fuentes et al. 2005). Cross-resistance between biocides and antibiotics could also be caused by cell wall modifications, reducing its permeability (European Commission 2009; Fraise 2011).

Besides several factors that can affect the activity of biocides such as contact time, temperature and target organism, their concentration is of particular importance with regard to the selection of antimicrobial resistant bacteria (Russell and McDonnell 2000). Coselection of antimicrobial resistance only occurs when bioavailable and bioacessible QAC concentrations do not exceed biocidal concentrations. While "in use" concentrations are typically multiples of the lethal dose (Bloomfield 2002), bioavailable and bioaccessible environmental concentrations of QACs are likely much lower, which might allow the co-selection of antimicrobial resistance. For example, it was shown that the exposure of bacteria to sub-lethal concentrations of QACs can select for antibiotic resistant mutants (Webber et al. 2015). In another study, a BAC-tolerant Salmonella enterica serotype Hvittingfoss S41 was obtained by in vitro exposure to the active component. Compared to the wild type, the BAC-tolerant Salmonella showed a significantly decreased susceptibility to 12 out of 24 antimicrobial compounds tested, belonging to eight antimicrobial classes (Condell et al. 2012). Long-term exposure of microbial communities developed from an inoculum of a contaminated sediment sample to sub-inhibitory concentrations of BACs resulted in a reduced diversity and an enrichment of Pseudomonas species. In parallel, the susceptibility to BACs as well as to the antibiotics penicillin $\mathrm{G}$, tetracycline and ciprofloxacin decreased, which was related to the degradation or transformation of these compounds and the activity of efflux pumps (Tandukar et al. 2013).

Biofilm formation seems to be another effective strategy of microorganisms to reduce the effectiveness of QACs. While repeated QAC exposure of drain isolates in pure culture could change their QAC susceptibility, domestic sink drain biofilm communities were recalcitrant to QAC exposure, and even longterm exposure to sub-lethal levels did not significantly affect their susceptibility to QACs or to antibiotics tested (McBain et al. 2004). Enterobacter sakazakii was less affected by disinfectants containing QACs when growing in biofilms than when dried on stainless steel or growing as plankton (Kim et al. 2007). It was shown that sub-MIC concentrations of BACs can even induce biofilm formation in Staphylococcus epidermis while inhibiting biofilm formation of other species (Houari and Di Martino 2007).

Besides cross-resistance discussed above, a main reason for the co-selection of resistance to QACs and antibiotics is the genetic linkage of genes for QAC tolerance and antibiotic resistance. The qac genes are commonly found on class 1 integrons, for example from clinical isolates (Gillings et al. 2009; Stalder et al. 2012). Class 1 integrons are able to accumulate, exchange, and express gene cassettes, which are known to carry resistance genes for almost all antibiotic families (Stalder et al. 2012). These integrons are also widespread in the environment such as agricultural soils (Gillings et al. 2014; Jechalke et al. 2014). This means that QACs can indirectly contribute to the enrichment of antibiotic resistance in the environment by co-selection processes. One of the first indications that QAACs can co-select for antibiotic resistance by the enrichment of class 1 integrons in environmental bacterial populations, was found in samples taken from a textile mill, a downstream reed bed, and river sediment contaminated with DTDMAC and ATMAC-C16 (Gaze et al. 2005). The authors observed that more than $95 \%$ of isolates carrying class 1 integrons also possessed the qacE gene. Integrons containing qac genes were also identified in biofilm samples collected from an urban stream by PCR amplification and cloning with subsequent sequencing (Gillings et al. 2009). Differences in amplification size indicated that class 1 integrons additionally contained gene cassettes, and sequencing revealed potential genes for antibiotic resistance. So far, more than 130 gene cassettes for almost all antibiotic families were reported, including beta-lactams, aminoglycosides, trimethoprim, chloramphenicol, fosfomycin, macrolides, lincosamides, rifampicin, and quinolones (Partridge et al. 2009; Stalder et al. 2012). 
Qac resistance genes and class 1 integrons are often embedded in plasmids or transposons, facilitating their spread within bacterial populations (Liebert et al. 1999; Partridge et al. 2001; Poole 2005; Gillings et al. 2014). These plasmids and transposons include multiresistance and heavy metal resistance plasmids as, for example reported for $q a c A$ and $q a c B$ genes, respectively (Russell 1997), but they were also associated with degradative pathways in a pesticide polluted environment (Dealtry et al. 2014). Class 1 integrons including qac genes are frequently found on IncP-1 plasmids which are broad host range plasmids widely distributed in the environment such as soil, manure, sludge, digestates and river sediments (Jechalke et al. 2015; Smalla et al. 2006; Zhang et al. 2011b; Heuer et al. 2012; Popowska and Krawczyk-Balska 2013; Wolters et al. 2015). For example, IncP-1 $\varepsilon$ plasmids were detected by qPCR in 16 manure samples and in arable soil (Heuer et al. 2012). Fifty IncP-1 plasmids were further analyzed and all carried class 1 integrons. Four plasmids were completely sequenced and revealed class 1 integrons associated with sull and qacEdeltal resistance genes and a variable gene cassette region.

Plasmids carrying qac resistance genes were also found in human pathogens. For example, a plasmid conferring resistance to kanamycin, gentamicin, tobramycin, amikacin, benzalkonium chloride, acriflavin, ethidium bromide and chlorhexidine (pSAJ1) was obtained from a gentamicin- and methicillinresistant Staphylococcus aureus (Yamamoto et al. 1988). Also for Staphylococcus aureus, a multiresistance conjugative plasmid carrying qacC and encoding resistance to trimethoprim ( $d f r A), \beta$-lactams (blaZ) and aminoglycosides (aacA-aphD) was described (Weigel et al. 2003), and $q a c A / B$ or $s m r$ genes were observed in methicillin-resistant $S$. aureus (MRSA) isolates, although in this case the presence of plasmids was not determined (Longtin et al. 2011). The QAC resistance genes qacE $\Delta 1$, sugE1 and sugE2 were colocalized on a multi-drug-resistance IncA/C plasmid (pSN254) isolated from Salmonella enterica serotype Newport SL254 (Welch et al. 2007). By investigating clinical isolates of Escherichia coli and Klebsiella pneumoniae, a class 1 integron was identified containing $b a_{\mathrm{IMP}-11}$ and $a a c A 1$ gene cassettes together with the 3' conserved region qacEAl and sull, which was likely carried by a transferable plasmid (Zhao et al. 2012). More recently, by screening a dataset of
2666 publicly available bacterial chromosomes and 1926 plasmids, an association was observed between the presence of biocide/metal resistance genes and antibiotic resistance genes, with qacE $\Delta l$ frequently detected on plasmids (Pal et al. 2015).

Comparative metagenomic analysis demonstrated for a microbial community sampled from contaminated river sediment that exposure to BACs for 3 years led to a decrease in phylogenetic diversity compared to the untreated control, mainly caused by an enrichment of Pseudomonas species in the BACfed communitites. Furthermore, while it was shown that biocide exposure led to an enrichment of multidrug efflux pumps as well as to a selection of genes associated with mobile genetic elements (Oh et al. 2013), it was also described that QAC resistance genes (qacEAl) can be enriched in soil by the application of sewage or manure containing antibiotics and heavy metals (Zhu et al. 2013).

\section{Perspectives}

Although there is growing evidence that QAACs can increase antibiotic resistance in environmental bacteria, a deeper understanding of the fate and ecotoxicological effects of QAACs applied to soils is necessary and crucial for a reliable risk assessment for human and environmental health. As identified in Box 1, the accumulation of QAACs on the surface and interlayers of clay minerals may form hot spots that lead to a longterm sub-inhibitory exposure of the associated microbial community. For judging the role of clay minerals for the sequestration and persistence of QAACs in soil, it is crucial to assess the kinetics and reversibility of QAAC movements into and out of interlayers of clay minerals. The function of clay mineral surfaces as hot spots for the selection of antibiotic resistant bacteria is also supported by the fact that the QAACs and also living and dead microbial biomass in soil are not evenly distributed but concentrated in the clay fraction (Kandeler et al. 2000; Amelung et al. 2002). In these hot spots on clay mineral surfaces, bacteria are therefore likely exposed to QAAC concentrations that are much larger than the average bulk soil concentrations typically reported. Hence, future studies should not only address concentrations and fate of QAACs in bulk soil, but also their distribution across soil constituents (clay minerals, oxides, organic matter), 
grain size fractions, and their microscale spatial distribution in relation to bacteria and root growth.

Acknowledgements We thank Luke Morgan of Texas A\&M University and Ilse-Marie Jungkurth for carefully reading and correcting the manuscript. This work was supported by the Federal Office for Agriculture and Food (Bundesanstalt für Landwirtschaft und Ernährung, BLE), Grant 13HS026 and by the DFG Research Project MU3988/1-1.

Open Access This article is distributed under the terms of the Creative Commons Attribution 4.0 International License (http:// creativecommons.org/licenses/by/4.0/), which permits unrestricted use, distribution, and reproduction in any medium, provided you give appropriate credit to the original author(s) and the source, provide a link to the Creative Commons license, and indicate if changes were made.

\section{References}

Alexandre B, Barbara G, Laure W et al (2016) Development of a multiple-class analytical method based on the use of synthetic matrices for the simultaneous determination of commonly used commercial surfactants in wastewater by liquid chromatography-tandem mass spectrometry. J Chromatogr A 1450:64-75. https://doi.org/10.1016/j. chroma.2016.04.078

Amelung W, Lobe I, Du Preez CC (2002) Fate of microbial residues in sandy soils of the South African Highveld as influenced by prolonged arable cropping. Eur J Soil Sci 53:29-35. https:// doi.org/10.1046/j.1365-2389.2002.00428.x

Andersson DI, Hughes D (2012) Evolution of antibiotic resistance at non-lethal drug concentrations. DRUG Resist Updat 15:162-172. https://doi.org/10.1016/j.drup.2012.03. 005

Asakawa T, Kitano H, Ohta A, Miyagishi S (2001) Convenient estimation for counterion dissociation of cationic micelles using chloride-sensitive fluorescence probe. J Colloid Interface Sci 242:284-287. https://doi.org/10.1006/jcis. 2001.7875

Babin D, Ding G-C, Pronk GJ et al (2013) Metal oxides, clay minerals and charcoal determine the composition of microbial communities in matured artificial soils and their response to phenanthrene. FEMS Microbiol Ecol 86:3-14. https://doi.org/10.1111/1574-6941.12058

Babin D, Vogel C, Zühlke S et al (2014) Soil mineral composition matters: response of microbial communities to phenanthrene and plant litter addition in long-term matured artificial soils. PLoS ONE 9:e106865. https://doi.org/10. 1371/journal.pone.0106865

Bailey SW (1980) Summary of recommendations of AIPEA Nomenclature Committee. Clays Clay Miner 28:73-78

Bassarab P, Williams D, Dean JR et al (2011) Determination of quaternary ammonium compounds in seawater samples by solid-phase extraction and liquid chromatography-mass spectrometry. J Chromatogr A 1218:673-677. https://doi. org/10.1016/j.chroma.2010.11.088
Behler A, Ansgar AW-M (2016) Quartäre Ammoniumverbindungen. In: RÖMPP online. Georg Thieme Verlag KG, Stuttgart

Bloomfield SF (2002) Significance of biocide usage and antimicrobial resistance in domiciliary environments. J Appl Microbiol 92(Suppl):144S-157S

Boethling R (1984) Environmental fate and toxicity in wastewater treatment of quaternary ammonium surfactants. Water Res 18:1061-1076. https://doi.org/10.1016/ 0043-1354(84)90220-3

Boethling RS, Lynch DG (1992) Quaternary ammonium surfactants. In: de Oude NT (ed) Detergents. Springer, Berlin, pp 145-177

Borchart N (1989) Smectites. Minerals in soil environments. Soil Science Society of America, Madison, pp 675-728

Boyaci E, Sparham C, Pawliszyn J (2014) Thin-film microextraction coupled to LC-ESI-MS/MS for determination of quaternary ammonium compounds in water samples. Anal Bioanal Chem 406:409-420. https://doi.org/10.1007/ s00216-013-7507-8

Bragg R, Jansen A, Coetzee M et al (2014) Bacterial resistance to quaternary ammonium compounds (QAC) disinfectants. In: Adhikari R, Thapa S (eds) Infectious diseases and nanomedicine II: first international conference (ICIDN2012), 15-18 Dec 2012, Kathmandu, Nepal. Springer India, New Delhi, pp 1-13

Brigatti MF, Galan E, Theng BKG (2006) Chapter 2: Structures and mineralogy of clay minerals. In: Faïza Bergaya BKGT, Lagaly G (eds) Developments in clay science. Elsevier, Amsterdam, pp 19-86

Calderbank A (1989) The occurrence and significance of bound pesticide residues in soil. In: Ware GW (ed) Reviews of environmental contamination and toxicology. Springer, New York, pp 71-103

Cepeda M, Daviña R, García-Río L et al (2013) Competition between surfactant micellization and complexation by cyclodextrin. Org Biomol Chem 11:1093-1102. https:// doi.org/10.1039/C2OB26318A

Chen Y (2014) Sorption behavior and acute toxicity of cationic surfactants in the aquatic environment. http://dspace. library.uu.nl/handle/1874/297722. Accessed 11 Jan 2017

Chen Y, Droge STJ, Hermens JLM (2012) Analyzing freely dissolved concentrations of cationic surfactant utilizing ion-exchange capability of polyacrylate coated solid-phase microextraction fibers. J Chromatogr A 1252:15-22. https://doi.org/10.1016/j.chroma.2012.06.080

Chen Y, Hermens JLM, Droge STJ (2013) Influence of organic matter type and medium composition on the sorption affinity of C12-benzalkonium cation. Environ Pollut 179:153-159. https://doi.org/10.1016/j.envpol.2013.04.017

Clara M, Scharf S, Scheffknecht C, Gans O (2007) Occurrence of selected surfactants in untreated and treated sewage. Water Res 41:4339-4348. https://doi.org/10.1016/j.watres. 2007.06.027

Clarke BO, Smith SR (2011) Review of "emerging" organic contaminants in biosolids and assessment of international research priorities for the agricultural use of biosolids. Environ Int 37:226-247. https://doi.org/10.1016/j.envint. 2010.06.004

Condell O, Iversen C, Cooney S et al (2012) Efficacy of biocides used in the modern food industry to control salmonella 
enterica, and links between biocide tolerance and resistance to clinically relevant antimicrobial compounds. Appl Env Microbiol 78:3087-3097

de Paiva LB, Morales AR, Valenzuela Díaz FR (2008) Organoclays: properties, preparation and applications. Appl Clay Sci 42:8-24. https://doi.org/10.1016/j.clay.2008.02.006

Dealtry S, Holmsgaard PN, Dunon V et al (2014) Shifts in abundance and diversity of mobile genetic elements after the introduction of diverse pesticides into an on-farm biopurification system over the course of a year. Appl Environ Microbiol 80:4012-4020

Deng Y, Dixon JB (2002) Soil organic matter and organicmineral interactions. Soil Mineral Environ Appl. https:// doi.org/10.2136/sssabookser7.c3

Ding WH, Liao YH (2001) Determination of alkylbenzyldimethylammonium chlorides in river water and sewage effluent by solid-phase extraction and gas chromatography/mass spectrometry. Anal Chem 73:36-40

Ding W-H, Tsai P-C (2003) Determination of alkyltrimethylammonium chlorides in river water by gas chromatography/ion trap mass spectrometry with electron impact and chemical ionization. Anal Chem 75:1792-1797

Ding G-C, Pronk GJ, Babin D et al (2013) Mineral composition and charcoal determine the bacterial community structure in artificial soils. FEMS Microbiol Ecol 86:15-25. https:// doi.org/10.1111/1574-6941.12070

Diress AG, Yassine MM, Lucy CA (2007) Semipermanent capillary coatings in mixed organic-water solvents for CE. Electrophoresis 28:1189-1196. https://doi.org/10.1002/ elps. 200600440

Droge STJ, Goss K-U (2013a) Ion-exchange affinity of organic cations to natural organic matter: influence of amine type and nonionic interactions at two different $\mathrm{pHs}$. Environ Sci Technol 47:798-806. https://doi.org/10.1021/es3033499

Droge STJ, Goss K-U (2013b) Sorption of organic cations to phyllosilicate clay minerals: CEC-normalization, salt dependency, and the role of electrostatic and hydrophobic effects. Environ Sci Technol 47:14224-14232. https://doi. org/10.1021/es403187w

DVG (2015) 13. Liste der nach Richtlinien der DVG (4. Auflage sowie 3. Auflage für Übergangszeit) geprüften und als wirksam befundenen Desinfektionsmittel für den Tierhaltebereich (Handelspräparate)

EIP-AGRI Focus Group on Reducing antibiotics in pig farming: Final report-EIP-AGRI-European Commission. In: EIP-AGRI/eip/agriculture/en/content/eip-agri-focusgroup-reducing-antibiotic-use-pig-farming-final-report. Accessed 23 Nov 2016

Ertekin E, Hatt JK, Konstantinidis KT, Tezel U (2016) Similar microbial consortia and genes are involved in the biodegradation of benzalkonium chlorides in different environments. Environ Sci Technol 50:4304-4313

EURL-SRM (2012) Methods for individual SRM-copounds: quaternary ammonium compounds (QAC). Last update: 14.09.2012 (V4). http://www.crl-pesticides.eu/userfiles/ file/EurlSRM/EurlSRM_meth_QAC_ShortMethod.pdf. Accessed 3 Jan 2016

European Commission (2009) Scientific committee on emerging and newly identified health risks. Assessment of the antibiotic resistance effects of biocides. http://ec.europa. eu/health/ph_risk/committees/04_scenihr/docs/scenihr_o_ 021.pdf

Fenger BH, Mandrup M, Rohde G, Kj JC (1973) Degradation of a cationic surfactant in activated sludge pilot plants. Water Res 7:1195-1208. https://doi.org/10.1016/0043-1354(73) 90072-9

Fernández P, Alder AC, Suter MJ, Giger W (1996) Determination of the quaternary ammonium surfactant ditallowdimethylammonium in digested sludges and marine sediments by supercritical fluid extraction and liquid chromatography with postcolumn ion-pair formation. Anal Chem 68:921-929. https://doi.org/10.1021/ac9505482

Ferrer I, Furlong ET (2001) Identification of alkyl dimethylbenzylammonium surfactants in water samples by solidphase extraction followed by ion trap LC/MS and LC/MS/ MS. Environ Sci Technol 35:2583-2588

Ferrer I, Furlong ET (2002) Accelerated solvent extraction followed by on-line solid-phase extraction coupled to ion trap LC/MS/MS for analysis of benzalkonium chlorides in sediment samples. Anal Chem 74:1275-1280

Förster M, Laabs V, Lamshöft M et al (2008) Analysis of aged sulfadiazine residues in soils using microwave extraction and liquid chromatography tandem mass spectrometry. Anal Bioanal Chem 391:1029-1038. https://doi.org/10. 1007/s00216-008-2081-1

Fraise A (2011) Currently available sporicides for use in healthcare, and their limitations. J Hosp Infect 77:210-212. https://doi.org/10.1016/j.jhin.2010.06.029

Frühling W, Ronnpagel K, Ahlf W (2001) Effect of zinc and benzalkonium chloride on Nitrosomonas communis and potential nitrification in soil. Environ Toxicol 16:439-443

Fuentes DE, Navarro CA, Tantaleán JC et al (2005) The product of the qacC gene of Staphylococcus epidermidis $\mathrm{CH}$ mediates resistance to beta-lactam antibiotics in gram-positive and gram-negative bacteria. Res Microbiol 156: 472-477. https://doi.org/10.1016/j.resmic.2005.01.002

García MT, Campos E, Sánchez-Leal J, Ribosa I (2000) Anaerobic degradation and toxicity of commercial cationic surfactants in anaerobic screening tests. Chemosphere 41:705-710. https://doi.org/10.1016/S0045-6535(99)00 $455-5$

Gaze WH, Abdouslam N, Hawkey PM, Wellington EMH (2005) Incidence of class 1 integrons in a quaternary ammonium compound-polluted environment. Antimicrob Agents Chemother 49:1802-1807

Gerba CP (2015) Quaternary ammonium biocides: efficacy in application. Appl Environ Microbiol 81:464-469. https:// doi.org/10.1128/AEM.02633-14

Gerike P, Klotz H, Kooijman JGA et al (1994) The determination of dihardenedtallowdimethyl ammonium compounds (DHTDMAC) in environmental matrices using trace enrichment techniques and high performance liquid chromatography with conductometric detection. Water Res 28:147-154. https://doi.org/10.1016/0043-1354(94)901 28-7

Gilbert P, Moore LE (2005) Cationic antiseptics: diversity of action under a common epithet. J Appl Microbiol 99: 703-715

Gillings MR, Holley MP, Stokes HW (2009) Evidence for dynamic exchange of qac gene cassettes between class 1 integrons and other integrons in freshwater biofilms. FEMS 
Microbiol Lett 296:282-288. https://doi.org/10.1111/j. 1574-6968.2009.01646.x

Gillings MR, Gaze WH, Pruden A et al (2014) Using the class 1 integron-integrase gene as a proxy for anthropogenic pollution. ISME J. https://doi.org/10.1038/ismej.2014.226

Grigson SJW, Wilkinson A, Johnson P et al (2000) Measurement of oilfield chemical residues in produced water discharges and marine sediments. Rapid Commun Mass Spectrom 14:2210-2219. https://doi.org/10.1002/10970231(20001215)14:23<2210:AID-RCM154>3.0.CO;2-8

Hatzinger PB, Alexander M (1995) Effect of aging of chemicals in soil on their biodegradability and extractability. Environ Sci Technol 29:537-545. https://doi.org/10.1021/ es00002a033

Hegstad K, Langsrud S, Lunestad BT et al (2010a) Does the wide use of quaternary ammonium compounds enhance the selection and spread of antimicrobial resistance and thus threaten our health? Microb Drug Resist 16:91-104

Hegstad K, Langsrud S, Lunestad BT et al (2010b) Does the wide use of quaternary ammonium compounds enhance the selection and spread of antimicrobial resistance and thus threaten our health? Microb Drug Resist Larchmt N 16:91-104. https://doi.org/10.1089/mdr.2009.0120

Heuer H, Binh CTT, Jechalke S et al (2012) IncP-1e plasmids are important vectors of antibiotic resistance genes in agricultural systems: diversification driven by class 1 integron gene cassettes. Front Microbiol. https://doi.org/ 10.3389/fmicb.2012.00002

Houari A, Di Martino P (2007) Effect of chlorhexidine and benzalkonium chloride on bacterial biofilm formation. Lett Appl Microbiol 45:652-656

Ioannou CJ, Hanlon GW, Denyer SP (2007) Action of disinfectant quaternary ammonium compounds against Staphylococcus aureus. Antimicrob Agents Chemother 51:296-306

Ishiguro M, Tan W, Koopal LK (2007) Binding of cationic surfactants to humic substances. Colloids Surf Physicochem Eng Asp 306:29-39. https://doi.org/10.1016/j. colsurfa.2006.12.024

Ismail ZZ, Tezel U, Pavlostathis SG (2010) Sorption of quaternary ammonium compounds to municipal sludge. Water Res 44:2303-2313. https://doi.org/10.1016/j.watres.2009. 12.029

Ivankovic T, Hrenovic J (2010) Surfactants in the environment. Arh ZA Hig RADA Toksikol-Arch Ind Hyg Toxicol 61:95-110. https://doi.org/10.2478/10004-1254-61-20101943

Jackson M, Eadsforth C, Schowanek D et al (2015) Comprehensive review of several surfactants in marine environment: fate and ecotoxicity. Environ Toxicol Chem. https:// doi.org/10.1002/etc.3297

Jaglic C, Cervinkova D (2012) Genetic basis of resistance to quaternary ammonium compounds - the qac genes and their role: a review. Vet Med (Praha) 57:275-281

Jardak K, Drogui P, Daghrir R (2016) Surfactants in aquatic and terrestrial environment: occurrence, behavior, and treatment processes. Environ Sci Pollut Res Int 23:3195-3216. https://doi.org/10.1007/s11356-015-5803-x

Jasmund K, Lagaly G (eds) (1993) Tonminerale und Tone. Steinkopff, Heidelberg
Jechalke S, Heuer H, Siemens J et al (2014) Fate and effects of veterinary antibiotics in soil. Trends Microbiol 22:536-545. https://doi.org/10.1016/j.tim.2014.05.005

Jechalke S, Broszat M, Lang F et al (2015) Effects of 100 years wastewater irrigation on resistance genes, class 1 integrons and IncP-1 plasmids in Mexican soil. Evol Genom Microbiol 6:163. https://doi.org/10.3389/fmicb.2015. 00163

Jennings MC, Minbiole KPC, Wuest WM (2015) Quaternary ammonium compounds: an antimicrobial mainstay and platform for innovation to address bacterial resistance. ACS Infect Dis 1:288-303. https://doi.org/10.1021/ acsinfecdis.5b00047

Juergensen L, Busnarda J, Caux P-Y, Kent RA (2000) Fate, behavior, and aquatic toxicity of the fungicide DDAC in the Canadian environment. Environ Toxicol 15:174-200. https://doi.org/10.1002/1522-7278(2000)15:3<174:AIDTOX4>3.0.CO;2-P

Kahrilas GA, Blotevogel J, Stewart PS, Borch T (2015) Biocides in hydraulic fracturing fluids: a critical review of their usage, mobility, degradation, and toxicity. Environ Sci Technol 49:16-32. https://doi.org/10.1021/es503724k

Kaiser K, Guggenberger G (2007) Distribution of hydrous aluminium and iron over density fractions depends on organic matter load and ultrasonic dispersion. Geoderma 140:140-146. https://doi.org/10.1016/j.geoderma.2007.03. 018

Kaj L, Wallberg P, Brorström-Lundén E (2014) Quaternary ammonium compounds: analyses in a Nordic cooperation on screening. Nordisk Ministerråd

Kandeler E, Tscherko D, Bruce KD et al (2000) Structure and function of the soil microbial community in microhabitats of a heavy metal polluted soil. Biol Fertil Soils 32:390-400. https://doi.org/10.1007/s003740000268

Kang HI, Shin HS (2016) Rapid and sensitive determination of benzalkonium chloride biocide residues in soil using liquid chromatography-tandem mass spectrometry after ultrasonically assisted extraction. Bull Korean Chem Soc 37:1219-1227. https://doi.org/10.1002/bkcs.10842

Keller BO, Sui J, Young AB, Whittal RM (2008) Interferences and contaminants encountered in modern mass spectrometry. Anal Chim Acta 627:71-81. https://doi.org/10.1016/j. aca.2008.04.043

Kim H, Ryu JH, Beuchat LR (2007) Effectiveness of disinfectants in killing Enterobacter sakazakii in suspension, dried on the surface of stainless steel, and in a biofilm. Appl Environ Microbiol 73:1256-1265

Klapyta Z, Fujita T, Iyi N (2001) Adsorption of dodecyl- and octadecyltrimethylammonium ions on a smectite and synthetic micas. Appl Clay Sci 19:5-10. https://doi.org/10. 1016/S0169-1317(01)00059-X

Koh S-M, Dixon JB (2001) Preparation and application of organo-minerals as sorbents of phenol, benzene and toluene. Appl Clay Sci 18:111-122. https://doi.org/10. 1016/S0169-1317(00)00040-5

Kümmerer K, Eitel A, Braun U et al (1997) Analysis of benzalkonium chloride in the effluent from European hospitals by solid-phase extraction and high-performance liquid chromatography with post-column ion-pairing and fluorescence detection. J Chromatogr A 774:281-286. https:// doi.org/10.1016/S0021-9673(97)00242-2 
Laabs V, Amelung W, Fent G et al (2002) Fate of 14C-labeled soybean and corn pesticides in tropical soils of Brazil under laboratory conditions. J Agric Food Chem 50:4619-4627. https://doi.org/10.1021/jf0115443

Lara-Martín PA, Li X, Bopp RF, Brownawell BJ (2010) Occurrence of alkyltrimethylammonium compounds in urban estuarine sediments: behentrimonium as a new emerging contaminant. Environ Sci Technol 44:7569-7575. https://doi.org/10.1021/es101169a

Lemić J, Tomašević-Čanović M, Djuričić M, Stanić T (2005) Surface modification of sepiolite with quaternary amines. J Colloid Interface Sci 292:11-19. https://doi.org/10.1016/ j.jcis.2005.05.080

Levsen K, Emmrich M, Behnert S (1993) Determination of dialkyldimethylammonium compounds and other cationic surfactants in sewage water and activated sludge. Fresenius J Anal Chem 346:732-737. https://doi.org/10.1007/ BF00321282

Levy SB (2002) Active efflux, a common mechanism for biocide and antibiotic resistance. J Appl Microbiol 92(Suppl): $65 \mathrm{~S}-71 \mathrm{~S}$

Li X, Brownawell BJ (2009) Analysis of quaternary ammonium compounds in estuarine sediments by LC-ToF-MS: very high positive mass defects of alkylamine ions provide powerful diagnostic tools for identification and structural elucidation. Anal Chem 81:7926-7935. https://doi.org/10. 1021/ac900900y

Li X, Brownawell BJ (2010) Quaternary ammonium compounds in urban estuarine sediment environments-a class of contaminants in need of increased attention? Environ Sci Technol 44:7561-7568. https://doi.org/10.1021/es1011669

Li X, Luo X, Mai B et al (2014a) Occurrence of quaternary ammonium compounds (QACs) and their application as a tracer for sewage derived pollution in urban estuarine sediments. Environ Pollut Barking Essex 185:127-133. https://doi.org/10.1016/j.envpol.2013.10.028

Li X, Luo X, Mai B et al (2014b) Occurrence of quaternary ammonium compounds (QACs) and their application as a tracer for sewage derived pollution in urban estuarine sediments. Environ Pollut 185:127-133. https://doi.org/10. 1016/j.envpol.2013.10.028

Liebert CA, Hall RM, Summers AO (1999) Transposon Tn21, flagship of the floating genome. Microbiol Mol Biol Rev 63:507-522

Longtin J, Seah C, Siebert K et al (2011) Distribution of antiseptic resistance genes qacA, qacB, and smr in methicillin-resistant Staphylococcus aureus isolated in Toronto, Canada, from 2005 to 2009. Antimicrob Agents Chemother 55:2999-3001. https://doi.org/10.1128/AAC.01707-10

Maillard JY (2007) Bacterial resistance to biocides in the healthcare environment: should it be of genuine concern? J Hosp Infect 65(Suppl 2):60-72

Marcotte L, Barbeau J, Lafleur M (2005) Permeability and thermodynamics study of quaternary ammonium surfactants-phosphocholine vesicle system. J Colloid Interface Sci 292:219-227. https://doi.org/10.1016/j.jcis.2005.05. 060

Martínez-Carballo E, González-Barreiro C, Sitka A et al (2007a) Determination of selected quaternary ammonium compounds by liquid chromatography with mass spectrometry. Part II. Application to sediment and sludge samples in Austria. Environ Pollut 146:543-547. https:// doi.org/10.1016/j.envpol.2006.07.016

Martínez-Carballo E, Sitka A, González-Barreiro C et al (2007b) Determination of selected quaternary ammonium compounds by liquid chromatography with mass spectrometry. Part I. Application to surface, waste and indirect discharge water samples in Austria. Environ Pollut 145:489-496. https://doi.org/10.1016/j.envpol.2006.04. 033

Martin-Sanchez PM, Novakova A, Bastian F et al (2012) Use of biocides for the control of fungal outbreaks in subterranean environments: the case of the Lascaux cave in France. Environ Sci Technol 46:3762-3770. https://doi.org/10. 1021/es2040625

Mayer LM (1999) Extent of coverage of mineral surfaces by organic matter in marine sediments. Geochim Cosmochim Acta 63:207-215. https://doi.org/10.1016/S00167037(99)00028-9

McBain AJ, Ledder RG, Moore LE et al (2004) Effects of quaternary-ammonium-based formulations on bacterial community dynamics and antimicrobial susceptibility. Appl Environ Microbiol 70:3449-3456

Merino F, Rubio S, Pérez-Bendito D (2003a) Solid-phase extraction of amphiphiles based on mixed hemimicelle/ admicelle formation: application to the concentration of benzalkonium surfactants in sewage and river water. Anal Chem 75:6799-6806. https://doi.org/10.1021/ac030224a

Merino F, Rubio S, Pérez-Bendito D (2003b) Mixed aggregatebased acid-induced cloud-point extraction and ion-trap liquid chromatography-mass spectrometry for the determination of cationic surfactants in sewage sludge. J Chromatogr A 998:143-154. https://doi.org/10.1016/S00219673(03)00565-X

Miura K, Nishiyama N, Yamamoto A (2008) Aquatic environmental monitoring of detergent surfactants. J Oleo Sci 57:161-170. https://doi.org/10.5650/jos.57.161

Mödl C, Wörmann H, Amelung W (2007) Contrasting effects of different types of organic material on surface area and microaggregation of goethite. Geoderma 141:167-173. https://doi.org/10.1016/j.geoderma.2007.05.003

Núñez O, Moyano E, Galceran MT (2004) Determination of quaternary ammonium biocides by liquid chromatography-mass spectrometry. J Chromatogr A 1058:89-95

Nye JV, Guerin WF, Boyd SA (1994) Heterotrophic activity of microorganisms in soils treated with quaternary ammonium compounds. Environ Sci Technol 28:944-951

Oh S, Tandukar M, Pavlostathis SG et al (2013) Microbial community adaptation to quaternary ammonium biocides as revealed by metagenomics. Environ Microbiol 15:2850-2864. https://doi.org/10.1111/1462-2920.12154

Olkowska E, Polkowska Ż, Namieśnik J (2013) A solid phase extraction-ion chromatography with conductivity detection procedure for determining cationic surfactants in surface water samples. Talanta 116:210-216. https://doi.org/ 10.1016/j.talanta.2013.04.083

Organisation for Economic Co-operation and Development (2009) OECD 2007 list of high production volume chemicals. OECD Environ Health Saf Publ Ser Test Assess 112:104

Pal C, Bengtsson-Palme J, Kristiansson E, Larsson DGJ (2015) Co-occurrence of resistance genes to antibiotics, biocides 
and metals reveals novel insights into their co-selection potential. BMC Genom. https://doi.org/10.1186/s12864015-2153-5

Partridge SR, Recchia GD, Stokes HW, Hall RM (2001) Family of class 1 integrons related to In 4 from Tn1696. Antimicrob Agents Chemother 45:3014-3020

Partridge SR, Tsafnat G, Coiera E, Iredell JR (2009) Gene cassettes and cassette arrays in mobile resistance integrons. FEMS Microbiol Rev 33:757-784. https://doi.org/10. 1111/j.1574-6976.2009.00175.x

Pateiro-Moure M, Arias-Estévez M, Simal-Gándara J (2013) Critical review on the environmental fate of quaternary ammonium herbicides in soils devoted to vineyards. Environ Sci Technol 47:4984-4998. https://doi.org/10. 1021/es400755h

Poole K (2005) Efflux-mediated antimicrobial resistance. J Antimicrob Chemother 56:20-51

Popowska M, Krawczyk-Balska A (2013) Broad-host-range IncP-1 plasmids and their resistance potential. Front Microbiol. https://doi.org/10.3389/fmicb.2013.00044

Pronk GJ, Heister K, Vogel C et al (2017) Interaction of minerals, organic matter, and microorganisms during biogeochemical interface formation as shown by a series of artificial soil experiments. Biol Fertil Soils 53:9-22. https://doi.org/10.1007/s00374-016-1161-1

Radke M, Behrends T, Forster J, Herrmann R (1999) Analysis of cationic surfactants by microbore high-performance liquid chromatography-electrospray mass spectrometry. Anal Chem 71:5362-5366. https://doi.org/10.1021/ac990453q

Ren R, Li K, Zhang C et al (2011) Biosorption of tetradecyl benzyl dimethyl ammonium chloride on activated sludge: kinetic, thermodynamic and reaction mechanisms. Bioresour Technol 102:3799-3804. https://doi.org/10.1016/j. biortech.2010.12.032

Ronnpagel K, Liss W, Ahlf W (1995) Microbial bioassays to assess the toxicity of solid-associated contaminants. Ecotoxicol Environ Saf 31:99-103

Ruan T, Song S, Wang T et al (2014) Identification and composition of emerging quaternary ammonium compounds in municipal sewage sludge in China. Environ Sci Technol 48:4289-4297. https://doi.org/10.1021/es4050314

Ruiz-Hitzky E, Van Meerbeek A (2006) Chapter 10.3: Clay mineral- and organoclay-polymer nanocomposite. In: Faïza Bergaya BKGT, Lagaly G (eds) Developments in clay science. Elsevier, Amsterdam, pp 583-621

Russell AD (1997) Plasmids and bacterial resistance to biocides. J Appl Microbiol 83:155-165

Russell AD, McDonnell G (2000) Concentration: a major factor in studying biocidal action. J Hosp Infect 44:1-3

Sánchez-Martín MJ, Dorado MC, del Hoyo C, Rodríguez-Cruz MS (2008) Influence of clay mineral structure and surfactant nature on the adsorption capacity of surfactants by clays. J Hazard Mater 150:115-123. https://doi.org/10. 1016/j.jhazmat.2007.04.093

Sarkar B, Megharaj M, Xi Y et al (2010) Sorption of quaternary ammonium compounds in soils: implications to the soil microbial activities. J Hazard Mater 184:448-456. https:// doi.org/10.1016/j.jhazmat.2010.08.055

Schampera B, Dultz S (2011) The effect of surface charge and wettability on $\mathrm{H}_{2} \mathrm{O}$ self diffusion in compacted clays. Clays
Clay Miner 59:42-57. https://doi.org/10.1346/CCMN. 2011.0590107

Schymanski EL, Singer HP, Longrée P et al (2014) Strategies to characterize polar organic contamination in wastewater: exploring the capability of high resolution mass spectrometry. Environ Sci Technol 48:1811-1818. https://doi. org/10.1021/es4044374

Semple KT, Doick KJ, Jones KC et al (2004) Defining bioavailability and bioaccessibility of contaminated soil and sediment is complicated. Environ Sci Technol 38:228A-231A

Shrivas K, Wu H-F (2007) A rapid, sensitive and effective quantitative method for simultaneous determination of cationic surfactant mixtures from river and municipal wastewater by direct combination of single-drop microextraction with AP-MALDI mass spectrometry. J Mass Spectrom 42:1637-1644. https://doi.org/10.1002/ jms. 1266

Singer AC, Shaw H, Rhodes V, Hart A (2016) Review of antimicrobial resistance in the environment and its relevance to environmental regulators. Front Microbiol. https://doi.org/10.3389/fmicb.2016.01728

Smalla K, Haines AS, Jones K et al (2006) Increased abundance of IncP-1 beta plasmids and mercury resistance genes in mercury-polluted river sediments: first discovery of IncP-1 beta plasmids with a complex mer transposon as the sole accessory element. Appl Environ Microbiol 72:7253-7259

Stalder T, Barraud O, Casellas M et al (2012) Integron involvement in environmental spread of antibiotic resistance. Front Microbiol 3:119. https://doi.org/10.3389/ fmicb.2012.00119

Steichen DS (2001) Chapter 14: cationic surfactants. In: Holmberg K (ed) Handbook of applied surface and colloid chemistry. Wiley, West Sussex, pp 309-347

Sütterlin H, Alexy R, Coker A, Kümmerer K (2008a) Mixtures of quaternary ammonium compounds and anionic organic compounds in the aquatic environment: elimination and biodegradability in the closed bottle test monitored by LCMS/MS. Chemosphere 72:479-484. https://doi.org/10. 1016/j.chemosphere.2008.03.008

Sütterlin H, Alexy R, Kümmerer K (2008b) The toxicity of the quaternary ammonium compound benzalkonium chloride alone and in mixtures with other anionic compounds to bacteria in test systems with Vibrio fischeri and Pseudomonas putida. Ecotoxicol Environ Saf 71:498-505. https://doi.org/10.1016/j.ecoenv.2007.12.015

Tandukar M, Oh S, Tezel U et al (2013) Long-term exposure to benzalkonium chloride disinfectants results in change of microbial community structure and increased antimicrobial resistance. Environ Sci Technol 47:9730-9738. https:// doi.org/10.1021/es401507k

Tezel U (2009) Fate and effect of quaternary ammonium compounds in biological systems. https://smartech.gatech.edu/ handle/1853/28229. Accessed 3 Jan 2016

Tezel U, Pavlostathis SG (2011) Role of quaternary ammonium compounds on antimicrobial resistance in the environment. In: Keen PL, Montfortsrk HMM (eds) antimicrobial resistance in the environment. Wiley, New York, pp 349-387

Tezel U, Pierson JA, Pavlostathis SG (2006) Fate and effect of quaternary ammonium compounds on a mixed 
methanogenic culture. Water Res 40:3660-3668. https:// doi.org/10.1016/j.watres.2006.06.019

Tezel U, Tandukar M, Martinez RJ et al (2012) Aerobic biotransformation of n-tetradecylbenzyldimethylammonium chloride by an enriched Pseudomonas spp. community. Environ Sci Technol 46:8714-8722

Totsche KU, Amelung W, Gerzabek MH et al (2017) Microaggregates in soils. J Plant Nutr Soil Sci. https://doi. org/10.1002/jpln.201600451

van Ginkel CG, Kolvenbach M (1991) Relations between the structure of quaternary alkyl ammonium salts and their biodegradability. Chemosphere 23:281-289. https://doi. org/10.1016/0045-6535(91)90184-F

van Wijk D, Gyimesi-van den Bos M, Garttener-Arends I et al (2009) Bioavailability and detoxification of cationics: I. Algal toxicity of alkyltrimethyl ammonium salts in the presence of suspended sediment and humic acid. Chemosphere 75:303-309. https://doi.org/10.1016/j.chemosphere. 2008.12.047

Vidal JLM, Vega AB, López FJS, Frenich AG (2004) Application of internal quality control to the analysis of quaternary ammonium compounds in surface and groundwater from Andalusia (Spain) by liquid chromatography with mass spectrometry. J Chromatogr A 1050:179-184

Walsh C, Fanning S (2008) Antimicrobial resistance in foodborne pathogens-a cause for concern? Curr Drug Targets 9:808-815

Wang P, Keller AA (2008) Partitioning of hydrophobic organic compounds within soil-water-surfactant systems. Water Res 42:2093-2101. https://doi.org/10.1016/j.watres.2007. 11.015

Warren CR (2013) Quaternary ammonium compounds can be abundant in some soils and are taken up as intact molecules by plants. New Phytol 198:476-485. https://doi.org/10. 1111/nph.12171

Webber MA, Whitehead RN, Mount M et al (2015) Parallel evolutionary pathways to antibiotic resistance selected by biocide exposure. J Antimicrob Chemother 70:2241-2248

Weber DJ, Rutala WA (2006) Use of germicides in the home and the healthcare setting: is there a relationship between germicide use and antibiotic resistance? Infect Control Hosp Epidemiol 27:1107-1119

Wee VT (1984) Determination of cationic surfactants in wasteand river waters. Water Res 18:223-225. https://doi.org/ 10.1016/0043-1354(84)90072-1

Weigel LM, Clewell DB, Gill SR et al (2003) Genetic analysis of a high-level vancomycin-resistant isolate of Staphylococcus aureus. Science 302:1569-1571. https://doi.org/10. 1126/science. 1090956

Welch TJ, Fricke WF, McDermott PF et al (2007) Multiple antimicrobial resistance in plague: an emerging public health risk. PLoS ONE 2:e309

Weston CW, Papcun JR, Dery M (2000) Ammonium compounds. In: Kirk-Othmer (ed) Kirk-Othmer encyclopedia of chemical technology. Wiley, London

White DG, McDermott PF (2001) Biocides, drug resistance and microbial evolution. Curr Opin Microbiol 4:313-317

Wien UBA (2005) Grundlagen zur Risikoabschätzung für quaternäre Ammoniumverbindungen. Umweltbundesamt $\mathrm{GmbH}$, Wien
Wolters B, Kyselková M, Krögerrecklenfort E et al (2015) Transferable antibiotic resistance plasmids from biogas plant digestates often belong to the IncP-1 epsilon subgroup. Front Microbiol 5:11

Xiang L, Sun T-F, Zheng M-J et al (2016) Sorption of dodecyltrimethylammonium chloride (DTAC) to agricultural soils. Sci Total Environ 560-561:197-203. https://doi.org/ 10.1016/j.scitotenv.2016.03.235

Xu S, Boyd SA (1995) Cationic surfactant adsorption by swelling and nonswelling layer silicates. Langmuir 11:2508-2514. https://doi.org/10.1021/la00007a033

Yamamoto T, Tamura Y, Yokota T (1988) Antiseptic and antibiotic resistance plasmid in Staphylococcus aureus that possesses ability to confer chlorhexidine and acrinol resistance. Antimicrob Agents Chemother 32:932-935

Yariv S, Cross H (2001) Organo-clay complexes and interactions. CRC Press, New York

Ying G-G (2006) Fate, behavior and effects of surfactants and their degradation products in the environment. Environ Int 32:417-431. https://doi.org/10.1016/j.envint.2005.07.004

Zabielska-Matejuk J, Czaczyk K (2006) Biodegradation of new quaternary ammonium compounds in treated wood by mould fungi. Wood Sci Technol 40:461-475. https://doi. org/10.1007/s00226-005-0065-2

Zanini GP, Ovesen RG, Hansen HCB, Strobel BW (2013) Adsorption of the disinfectant benzalkonium chloride on montmorillonite. Synergistic effect in mixture of molecules with different chain lengths. J Environ Manag 128:100-105. https://doi.org/10.1016/j.jenvman.2013.04. 056

Zarfl C, Klasmeier J, Matthies M (2009) A conceptual model describing the fate of sulfadiazine and its metabolites observed in manure-amended soils. Chemosphere 77:720-726. https://doi.org/10.1016/j.chemosphere.2009. 08.035

Zhang C, Tezel U, Li K et al (2011a) Evaluation and modeling of benzalkonium chloride inhibition and biodegradation in activated sludge. Water Res 45:1238-1246. https://doi.org/ 10.1016/j.watres.2010.09.037

Zhang T, Zhang X-X, Ye L (2011b) Plasmid metagenome reveals high levels of antibiotic resistance genes and mobile genetic elements in activated sludge. PLoS ONE 6:e26041. https://doi.org/10.1371/journal.pone.0026041

Zhang C, Cui F, Zeng G et al (2015) Quaternary ammonium compounds (QACs): A review on occurrence, fate and toxicity in the environment. Sci Total Environ 518-519:352-362. https://doi.org/10.1016/j.scitotenv.2015. 03.007

Zhao W-H, Chen G, Ito R et al (2012) Identification of a plasmid-borne blaIMP-11 gene in clinical isolates of Escherichia coli and Klebsiella pneumoniae. J Med Microbiol 61:246-251. https://doi.org/10.1099/jmm.0.035626-0

Zhu L, Chen B, Tao S, Chiou CT (2003) Interactions of organic contaminants with mineral-adsorbed surfactants. Environ Sci Technol 37:4001-4006

Zhu Y-G, Johnson TA, Su J-Q et al (2013) Diverse and abundant antibiotic resistance genes in Chinese swine farms. Proc Natl Acad Sci U S A 110:3435-3440. https://doi.org/10. 1073/pnas. 1222743110 